\title{
Ocean biogeochemistry in the warm climate of the late Paleocene
}

\author{
M. Heinze ${ }^{1,2}$ and T. Ilyina ${ }^{1}$ \\ ${ }^{1}$ Max Planck Institute for Meteorology, Bundesstrasse 53, 20146 Hamburg, Germany \\ ${ }^{2}$ International Max Planck Research School on Earth System Modelling, Hamburg, Germany \\ Correspondence to: M. Heinze (mathias.heinze@ mpimet.mpg.de)
}

Received: 24 March 2014 - Published in Clim. Past Discuss.: 28 April 2014

Revised: 28 October 2014 - Accepted: 17 November 2014 - Published: 13 January 2015

\begin{abstract}
The late Paleocene is characterized by warm and stable climatic conditions that served as the background climate for the Paleocene-Eocene Thermal Maximum (PETM, $\sim 55$ million years ago). With respect to feedback processes in the carbon cycle, the ocean biogeochemical background state is of major importance for projecting the climatic response to a carbon perturbation related to the PETM. Therefore, we use the Hamburg Ocean Carbon Cycle model (HAMOCC), embedded in the ocean general circulation model of the Max Planck Institute for Meteorology, MPIOM, to constrain the ocean biogeochemistry of the late Paleocene. We focus on the evaluation of modeled spatial and vertical distributions of the ocean carbon cycle parameters in a longterm warm steady-state ocean, based on a $560 \mathrm{ppm} \mathrm{CO}_{2}$ atmosphere. Model results are discussed in the context of available proxy data and simulations of pre-industrial conditions. Our results illustrate that ocean biogeochemistry is shaped by the warm and sluggish ocean state of the late Paleocene. Primary production is slightly reduced in comparison to the present day; it is intensified along the Equator, especially in the Atlantic. This enhances remineralization of organic matter, resulting in strong oxygen minimum zones and $\mathrm{CaCO}_{3}$ dissolution in intermediate waters. We show that an equilibrium $\mathrm{CO}_{2}$ exchange without increasing total alkalinity concentrations above today's values is achieved. However, consistent with the higher atmospheric $\mathrm{CO}_{2}$, the surface ocean $\mathrm{pH}$ and the saturation state with respect to $\mathrm{CaCO}_{3}$ are lower than today. Our results indicate that, under such conditions, the surface ocean carbonate chemistry is expected to be more sensitive to a carbon perturbation (i.e., the PETM) due to lower $\mathrm{CO}_{3}^{2-}$ concentration, whereas the deep ocean calcite sediments would be less vulnerable to dissolution due to the vertically stratified ocean.
\end{abstract}

\section{Introduction}

The late Paleocene has received interest because of its role as the background climate for the Paleocene-Eocene Thermal Maximum (PETM), which could have been a possible ana$\log$ for present-day greenhouse warming and ocean acidification (e.g., Zachos et al., 2005; Ridgwell and Zeebe, 2005; Zeebe and Zachos, 2013). The PETM describes a time period of about $170 \mathrm{kyr}$, which is characterized by an increase in mean surface temperatures of more than $5^{\circ}$ (Kennett and Stott, 1991; Dickens et al., 1995; Zachos et al., 2008). During the PETM, the atmospheric $\mathrm{CO}_{2}$ values increased significantly over a relatively short time period of about $10 \mathrm{kyr}$ (Panchuk et al., 2008). Nonetheless, the question about the exact atmospheric $\mathrm{CO}_{2}$ content before the PETM, as well as the maximum values of $\mathrm{CO}_{2}$ during the PETM, still remains unanswered (e.g., Pagani et al., 2006a).

The climate of the late Paleocene was characterized by higher global average temperatures than in the present day, bearing ice-free conditions at the poles (Zachos et al., 2001). The pole-to-equator temperature gradient was smaller, displayed in sea surface temperatures (SST) of more than $30^{\circ}$ in the tropics (Pearson et al., 2001) and up to $20^{\circ}$ at high latitudes (Sluijs et al., 2006; Lunt et al., 2012). Deep ocean water masses were up to $10^{\circ}$ warmer compared to modern values (Kennett and Stott, 1991; Zachos et al., 2008; Tripati and Elderfield, 2005). The warmer climate and the late Paleocene continental configuration influenced global ocean circulation patterns. The main deepwater formation occurred at southern high latitudes, with additional minor regions of deepwater formation in the Northern Hemisphere (Thomas et al., 2003). There is no consensus as to whether the Northern Hemisphere deepwater formation was stronger 
in the Atlantic or the Pacific (e.g., Bice and Marotzke, 2002; Tripati and Elderfield, 2005; Nunes and Norris, 2006).

Hitherto, the focus of modeling the late Paleocene with complex earth system models (ESM) was set to the physical ocean and the atmospheric system (Huber and Sloan, 2001; Heinemann et al., 2009; Winguth et al., 2010). Studies of the PETM background climate show a wide range of intermodel variability, using prescribed atmospheric $\mathrm{CO}_{2}$ concentrations ranging from $2 \times$ to $16 \times$ pre-industrial $\mathrm{CO}_{2}$ (Lunt et al., 2012). In previous studies, the late Paleocene ocean biogeochemistry has been addressed exclusively with earth system models of intermediate complexity (EMIC) or box models (e.g., Panchuk et al., 2008; Zeebe et al., 2009; Ridgwell and Schmidt, 2010; Winguth et al., 2012). These modeling studies cover the whole PETM, with the major objective of constraining the absolute amount of the carbon perturbation. Their approach is based on reconstructions of the calcium carbonate compensation depth (CCD). By observing vertical shifts in the $\mathrm{CaCO}_{3}$ dissolution horizons in sediment cores, before and after the peak of the event, rough estimates of the carbon perturbation during the PETM can be obtained. The depth of the pre-PETM CCD is still under discussion for wider geographical areas of the late Paleocene oceans (Zeebe and Zachos, 2013). This leads to quite different estimates of total carbon mass and carbon injection speed into the climate system necessary for obtaining the observed sedimentary $\mathrm{CaCO}_{3}$ dissolution (Dunkley Jones et al., 2010). Hence, the preceding conditions of ocean biogeochemistry are important for a realistic assessment of the PETM itself in order to gain knowledge about ocean biogeochemistry influence on feedback mechanisms for the PETM, e.g., alterations in the carbonate buffer capacity. However, estimates of, for instance, total alkalinity (TA) and dissolved inorganic carbon (DIC) during the late Paleocene, are not well known at present (Dunkley Jones et al., 2010).

In order further to constrain the state of the oceanic part of the carbon cycle during the late Paleocene, we spin up and run the Hamburg Ocean Carbon Cycle model, HAMOCC, and the ocean general circulation model (OGCM) of the Max Planck Institute for Meteorology, MPIOM, under late Paleocene boundary conditions into an equilibrium state. Estimates for late Paleocene atmospheric $\mathrm{CO}_{2}$ concentrations range from 600 to $2800 \mathrm{ppm}$ Pagani et al. (2006a). Based on Heinemann et al. (2009), we use a $560 \mathrm{ppm} \mathrm{CO}_{2}$ late Paleocene atmospheric forcing to achieve a plausible background climate for the PETM. The applied atmospheric $\mathrm{CO}_{2}$ concentrations and late Paleocene boundary conditions cause a new equilibrium climate state, which fits the proxy-record-based SST quite well (Lunt et al., 2012). However, the pre-PETM ocean biogeochemistry is not only affected by modifications in temperature and atmospheric conditions at the oceanatmosphere boundary (Archer et al., 2004), but also by alterations in the general ocean physical state. Hence, using a state-of-the-art OGCM-based carbon cycle model, we address the following questions. (i) How does the enhanced ver- tical stratification of the ocean affect the marine carbon cycle? (ii) What is the effect of the higher background steadystate $\mathrm{CO}_{2}$ on the marine carbonate chemistry?

The model used has been applied in a number of previous studies simulating the pre-industrial, modern and future climate/ocean states, for example in the framework of the Climate Model Intercomparison Project (CMIP5; Ilyina et al., 2013). Therefore, here we also use the model output of the CMIP5 experiments for comparison. The model output is based on calculations with the Max Planck Institute for Meteorology-Earth System Model (MPI-ESM) for preindustrial (1850-1879) climatic conditions.

In Sect. 2 of this paper, we describe the model and give detailed information on the spin-up of HAMOCC under late Paleocene conditions. The general late Paleocene climate state achieved by our simulation is presented in Sect. 3. Section 4 comprises the results of the modeled ocean biogeochemistry, followed by the conclusions in Sect. 5 .

\section{Model description and setup}

\subsection{The ocean biogeochemistry model HAMOCC}

For our study, we employ the Hamburg Ocean Carbon Cycle (HAMOCC 5.1) model, which is based on MaierReimer (1993) and successive refinements (Maier-Reimer et al., 2005). HAMOCC simulates 18 biogeochemical tracers in the oceanic water column and 12 tracers in the upper $14 \mathrm{~cm}$ of the sediment. The tracers are simulated prognostically within a three-dimensional ocean circulation state. HAMOCC is coupled online to the Max Planck Institute ocean model (MPIOM) (Marsland et al., 2003; Jungclaus et al., 2013), which computes tracer advection and mixing. Temperature, pressure and salinity of MPIOM are used to calculate various transformation rates and chemical constants within HAMOCC. The treatment of important biogeochemical processes in HAMOCC, related to this study, is described in some more detail in the following paragraphs. For more complete information on HAMOCC, see Ilyina et al. (2013) and Maier-Reimer et al. (2005).

Air-sea gas exchange is calculated for $\mathrm{O}_{2}, \mathrm{CO}_{2}$ and $\mathrm{N}_{2}$. The air-sea $\mathrm{CO}_{2}$ flux is a result of the partial pressure difference between atmosphere and water multiplied by a gas exchange rate and solubility according to Weiss (1974) and Groeger and Mikolajewicz (2011). It is then divided by the actual thickness of the surface layer. The velocity of the gas transfer depends on the Schmidt number and prognostic wind speed at the surface (Wanninkhof, 1992). The oceanic partial pressure of $\mathrm{CO}_{2}\left(p \mathrm{CO}_{2}\right)$ in the model is prognostically computed as a function of temperature, salinity, DIC, TA, and pressure.

Biological processes are described by an extended NPZD (nutrient-phytoplankton-zooplankton-detritus) type model (Six and Maier-Reimer, 1996). Primary production in 
HAMOCC is based on the co-limitation of phosphorous, nitrate and iron, as well as on temperature and radiation. The biogeochemical processes within the model are calculated on the basis of phosphorous. Associated changes between the remaining tracers are calculated using constant stoichiometric ratios (Redfield ratio following Takahashi et al. (1985); $\mathrm{P}: \mathrm{N}: \mathrm{C}:-\mathrm{O}_{2}$ ratio of $\left.1: 16: 122: 172\right)$. Phytoplankton are divided into silicifiers (opal shells) and calcifiers $\left(\mathrm{CaCO}_{3}\right.$ shells). It is assumed that silicifiers are preferentially produced as long as silicate is available, which is shown by several observational studies (e.g., Lochte et al., 1993). Via prescribed vertical sinking rates, opal, $\mathrm{CaCO}_{3}$ and particulate organic carbon (POC) are transported to depth. During the sinking, the particles undergo remineralization at a constant rate, distributing silicate, DIC, TA and nutrients (while decreasing oxygen) at depth. Remineralization of POC depends on oxygen. If oxygen falls below a concentration of $0.5 \mu \mathrm{mol} \mathrm{L}-1$, organic matter is decomposed by denitrification and sulfate reduction.

The formation of $\mathrm{CaCO}_{3}$ shells consumes DIC and TA in a molar ratio of $1: 2$. The dissolution of $\mathrm{CaCO}_{3}$ at depth is a function of the calcite saturation state $(\Omega)$ of sea water and a dissolution rate constant. $\Omega$ is calculated from $\mathrm{Ca}^{2+}$ concentration in sea water, which is kept constant at $1.03 \times 10^{-2} \mathrm{kmol} \mathrm{m}^{-3}, \mathrm{CO}_{3}^{2-}$ (carbonate ion) concentration and the apparent solubility product of calcite, based on temperature and pressure. Dissolution of opal takes place continuously over the whole water column at a rate of $0.01 \mathrm{~d}^{-1}$. While $\mathrm{CaCO}_{3}$ is less soluble in warm waters, the dissolution intensity of opal is positively correlated with temperature (Ragueneau et al., 2000).

The sediment module is based on Heinze and MaierReimer (1999) and Heinze et al. (1999). It basically calculates the same tracers as the water column model. The solid components of the sediment comprise opal, $\mathrm{CaCO}_{3}$, organic carbon and chemically inert dust (referred to from here onwards as "clay"). The liquid sediment components (pore water tracer) are DIC, TA, $\mathrm{PO}_{4}, \mathrm{O}_{2}, \mathrm{~N}_{2}, \mathrm{NO}_{3}, \mathrm{Si}(\mathrm{OH})_{4}$ and $\mathrm{Fe}$. The tracer concentrations within the oceanic bottom layer, and particularly the particle deposition from it, determine the upper boundary for the sediment. The sediment consists of 12 biologically active layers, with increasing thickness and decreasing porosity from top to bottom representing the uppermost $14 \mathrm{~cm}$ of the ocean floor. Below the active sediment there is one diagenetically consolidated layer (burial) containing only solid sediment components and representing the bedrock. Major processes simulated in the sediment are vertical diffusion of porewater, decomposition of detritus, as well as dissolution of opal and $\mathrm{CaCO}_{3}$.

\subsection{Topography and grid}

The model setup is based on the interpolation of a late Paleocene $2^{\circ} \times 2^{\circ}$ topography (Bice and Marotzke, 2001) onto our $3.5^{\circ} \times 3.5^{\circ}$ ocean model grid (Fig. 1). It is used in

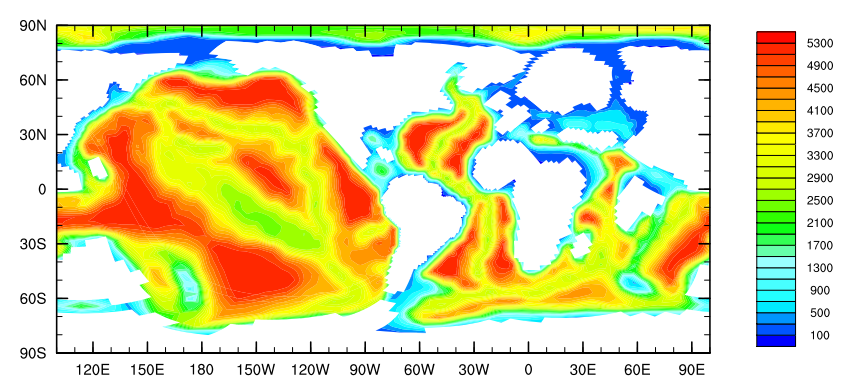

Figure 1. Paleocene topography (m depth).

several Paleocene-Eocene climate studies (Panchuk et al., 2008; Roberts et al., 2009; Heinemann et al., 2009; Zeebe, 2012). The main differences to present-day bathymetry lie in the open Central American Seaway, connecting the Atlantic and Pacific, as well as the existence of the Tethys Ocean and its connection to the Arctic Ocean, via the Turgai Strait. Although the Arctic Ocean has an additional link to the surrounding oceans, it lacks, unlike the present-day bathymetry, a deepwater connection. In the Southern Hemisphere, the Drake Passage and the Tasmanian Seaway are already open, but operate just as shallow water connections around Antarctica. The average ocean floor depth amounts to $3135 \mathrm{~m}$ (present-day setup: $3700 \mathrm{~m}$ ) and has its deepest point at $5287 \mathrm{~m}$ (present-day setup: $5958 \mathrm{~m}$ ) in the eastern equatorial Pacific. Vast areas of the Pacific are shallower in depth than in the modern ocean, the Atlantic is narrower than today, and almost the whole Tethys does not exceed depths of $1000 \mathrm{~m}$. It is mainly shaped by extended shelf areas. Taking into account these differences, the model bathymetry yields a $14 \%$ reduced sea water volume compared to today's ocean. Although the missing ice sheets in the late Paleocene setup would suggest an increase in oceanic volume, the provided bathymetry from Bice and Marotzke (2001) results in a reduced ocean volume compared to modern conditions. However, since we adapt the inventories of the ocean biogeochmical tracers (see "Initialization biogeochemistry"), we hold on to the reduced ocean volume bathymetry, since it allows a better comparison of the results to other models using the same bathymetry (e.g., Panchuk et al., 2008; Heinemann et al., 2009).

In the conducted simulations, HAMOCC integrates with a time step of $2.4 \mathrm{~h}$ ( 0.1 days). The horizontal resolution of the ocean model is $3.5^{\circ} \times 3.5^{\circ}$, which equals a grid spacing from $70 \mathrm{~km}$ around South America to $430 \mathrm{~km}$ in the Pacific. The ocean model has 40 vertical layers, with increasing level thicknesses with depth: 9 layers cover the upper $100 \mathrm{~m}$ and 23 layers the upper $1000 \mathrm{~m}$ of the water column. An orthogonal curvilinear grid is applied, with the poles located over northern Eurasia and South America to achieve the best grid resolution for all ocean regions. 


\subsection{Forcing}

The ocean stand-alone model approach requires an atmospheric forcing. We use a late Paleocene climate with an atmospheric $\mathrm{CO}_{2}$ concentration of $560 \mathrm{ppm}$, which is mimicked by an adequate atmospheric forcing, derived from Heinemann et al. (2009). The atmospheric conditions used in this study were calculated with a coupled climate model using ECHAM5, MPIOM and JSBACH under PaleoceneEocene boundary conditions $\left(560 \mathrm{ppm} \mathrm{CO}_{2}\right)$. Atmospheric methane and nitrous oxide are set to pre-industrial values. The model shows, after 2300 years of integration, an equilibrium state in atmospheric and oceanic conditions (Heinemann et al., 2009). From the atmospheric model output, we take 30 consecutive years, from which we reproduce a daily mean late Paleocene atmospheric forcing based on the Ocean Model Intercomparison Project (OMIP) forcing used for present-day ocean-model-only setups (Roeske, 2006). The model is then forced using daily heat, freshwater and momentum fluxes in a 30 year cycle.

We initialize the stand-alone ocean model (MPIOM) based on the result of the 2300 year late Paleocene equilibrium run by Heinemann et al. (2009). Additionally, we define a Paleocene climatology for ocean temperature and salinity from the same data. It displays the monthly mean climatological state for the two variables, averaged from daily data over a 30 year period. Sea surface salinity (SSS) and SST (upper $12 \mathrm{~m}$ ) in our model are relaxed towards this Paleocene-based climatology. Relaxation takes place with a time constant of 180 days; it takes about 3 months till the surface layer is restored completely to the climatology.

\subsection{Initialization of biogeochemistry}

Using the MPIOM physical ocean state, we spin up HAMOCC starting from basin-wide homogeneous distributions of biogeochemical tracers, taking pre-industrial concentrations as a rough orientation for spatial and vertical tracer distributions. We reduce the oceanic carbon inventory (from $\sim 38500 \mathrm{Gt}$ to $\sim 32000 \mathrm{Gt}$ ), as well as the different nutrient pools, proportionally to the $14 \%$ reduced ocean volume in the late Paleocene setup. The reduction results in tracer concentrations close to modern values in the water column.

The model is integrated for 3200 years, periodically repeating the forcing (see Sect. 2.3), while the inventories of TA are adjusted to the $\mathrm{CO}_{2}$ level of $560 \mathrm{ppm}$. Fluxes and tracer distribution stabilize after about 1000 model years within the water column. The distributions of tracers are not restored to any kind of data set, to be consistent with the biological, chemical, and physical dynamics of the model.

Since, for the late Paleocene, the monthly mean dust deposition fields are not available (A. Winguth, personal communication, 2013), we prescribe a spatially homogeneous in- put of dust at the sea surface. The total amount of annual bio-available iron deposition to the ocean is the same as in the modern ocean setup $\left(\sim 38 \times 10^{7} \mathrm{~kg} \mathrm{Fe} \mathrm{yr}^{-1}\right.$; Mahowald et al., 2005). Besides the inventory adaptation and homogeneous dust deposition, the ocean chemistry in the late Paleocene simulations is modeled the same as in the modern MPI-ESM (Ilyina et al., 2013).

The weathering fluxes depend on the long-term sedimentation rates. They are used for balancing the water column inventory of the calcite, silicate and OM pools. The annual amount leaving the system through sedimentation is added (globally distributed) at the surface again. The calcite weathering varies from 0 to $900 \mathrm{kmol} \mathrm{C} \mathrm{s}^{-1}$. Silicate weathering varies from 0 to $650 \mathrm{kmol} \mathrm{Si} \mathrm{s}^{-1}$, and organic material varies from 0 to $4 \mathrm{kmol} \mathrm{C} \mathrm{s}^{-1}$ during the spin-up. After establishing an equilibrium state in the sediment, constant weathering fluxes are applied, as shown in Table 1.

\subsection{Initialization of sediment}

An equilibrium sediment state exists for the present-day model configuration of HAMOCC, which is based on long spin-up simulations of approximately $50 \mathrm{kyr}$ (e.g., Heinze et al., 1999). Since an equilibrium sediment state is missing for the Paleocene model configuration of HAMOCC, we initialize the sediment with $100 \%$ clay, while the $\mathrm{CaCO}_{3}$, opal and organic carbon sediment pools start filling from the first year on. However, in matters of computing time, it is not feasible to spin up the sediment module and achieve an equilibrium state within a realistic time frame. To circumvent this problem, we use a computational method to accelerate processes within the sediment module of HAMOCC: we reduce the surface area of the sediment grid boxes (underlying the oceanic bottom layer) by a desired acceleration factor (in this study, 1000), while keeping their vertical extent constant. By using this method, the volume of the sediment grid boxes is effectively reduced. Accordingly, the amount and composition of material that is exported from the oceanic bottom layer and deposited at the sediment surface is distributed faster over the whole sediment column. Since we want to maintain the same dissolution behavior throughout the acceleration process within the sediment, we have to reduce the porewater diffusion by the same factor we apply for the area reduction.

From a modeling perspective, this computational acceleration is acceptable, since the proportion of the single grid cells $(100 \mathrm{~km} \times 15 \mathrm{~cm})$ prevents horizontal gradients in the sediment module. Moreover, this method provides a way to accelerate sedimentation processes, while mass conservation is maintained in both, the water column and the sediment module. As soon as the sediment reaches an equilibrium-like state, the sediment surface is extended to its original area and the porewater diffusion is set back.

In our simulation, this sediment acceleration is turned on in year 1350 , after having the water column tracers close to 
Table 1. Globally integrated values of biogeochemical parameters calculated with HAMOCC for the pre-industrial (CMIP5, Ilyina et al., 2013) and the late Paleocene.

\begin{tabular}{|c|c|c|}
\hline & $\begin{array}{r}\text { Pre-industrial } \\
\text { (CMIP 5) }\end{array}$ & $\begin{array}{r}\text { Late } \\
\text { Paleocene }\end{array}$ \\
\hline Atmospheric $\mathrm{CO}_{2}(\mathrm{ppm})$ & 278 & 560 \\
\hline Ocean volume $\left(10^{18} \mathrm{~m}^{3}\right)$ & 1.353 & 1.164 \\
\hline Ocean temperature surface $\left({ }^{\circ} \mathrm{C}\right)$ & 9.6 & 24.8 \\
\hline Ocean temperature at $4000 \mathrm{~m} \operatorname{depth}\left({ }^{\circ} \mathrm{C}\right)$ & 1.4 & 8.9 \\
\hline Ocean salinity & 34.67 & 34.31 \\
\hline \multicolumn{3}{|l|}{ Inventories } \\
\hline Carbon $\left(10^{3} \mathrm{Gt}\right)$ & 38.5 & 32.0 \\
\hline Phosphate $\left(10^{12} \mathrm{kmol}\right)$ & 2.73 & 2.48 \\
\hline Silicate $\left(10^{14} \mathrm{kmol}\right)$ & 1.64 & 1.88 \\
\hline Nitrate $\left(10^{13} \mathrm{kmol}\right)$ & 3.44 & 2.84 \\
\hline \multicolumn{3}{|l|}{ Weathering } \\
\hline Global input of $\mathrm{CaCO}_{3}\left(\mathrm{Tmol} \mathrm{yr}^{-1}\right)$ & 28.4 & 22.1 \\
\hline Global input of opal $\left(\mathrm{Tmol} \mathrm{yr}^{-1}\right)$ & 6.5 & 0 \\
\hline Global input of POC $\left(\mathrm{Tmol} \mathrm{yr}^{-1}\right)$ & 0 & 0.1 \\
\hline \multicolumn{3}{|l|}{ Primary production } \\
\hline 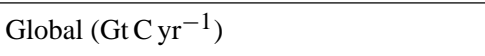 & 61.14 & 58.65 \\
\hline \multicolumn{3}{|l|}{ Export production } \\
\hline $\mathrm{CaCO}_{3}\left(\mathrm{GtC} \mathrm{yr}^{-1}\right)$ & 0.89 & 0.63 \\
\hline Opal (Tmol Si yr $\left.{ }^{-1}\right)$ & 118.24 & 159.57 \\
\hline $\mathrm{POC}\left(\mathrm{GtC} \mathrm{yr}^{-1}\right)$ & 8.72 & 8.54 \\
\hline \multicolumn{3}{|l|}{ Molar export ratio } \\
\hline $\mathrm{C}\left(\mathrm{CaCO}_{3}\right): \mathrm{Si}($ opal $)$ & 0.63 & 0.33 \\
\hline $\mathrm{C}\left(\mathrm{CaCO}_{3}\right): \mathrm{C}(\mathrm{POC})$ & 0.1 & 0.07 \\
\hline $\mathrm{Si}($ opal $): \mathrm{C}(\mathrm{POC})$ & 0.16 & 0.22 \\
\hline \multicolumn{3}{|l|}{ N cycle } \\
\hline $\mathrm{N}_{2}$ fixation $\left(\mathrm{Tmol} \mathrm{Nyr}^{-1}\right)$ & 14.89 & 22.33 \\
\hline Denitrification $\left(\mathrm{Tmol} \mathrm{N} \mathrm{yr}^{-1}\right)$ & 14.53 & 21.18 \\
\hline
\end{tabular}

an equilibrium state. After approximately 150 years, the net fluxes at the ocean-sediment boundary are strongly reduced (indicating an equilibrium-like state), and the sediment acceleration is turned off. In this way, accumulation of the sediment pool is roughly equivalent to 150000 years..

\section{Late Paleocene climate state}

The late Paleocene climate state in our simulation is characterized by a global annual mean temperature of $23.6^{\circ} \mathrm{C}$ (at $2 \mathrm{~m}$ in height), using the atmospheric forcing described above (for a comparison, see Lunt et al., 2012). Maximum annual average temperatures are reached along the Equator over Africa, Asia and South America, with temperatures close to $40^{\circ} \mathrm{C}$ (Fig. 2). The absolute annual average heat maximum lies over southern Asia $\left(42.1{ }^{\circ} \mathrm{C}\right)$. Southern high

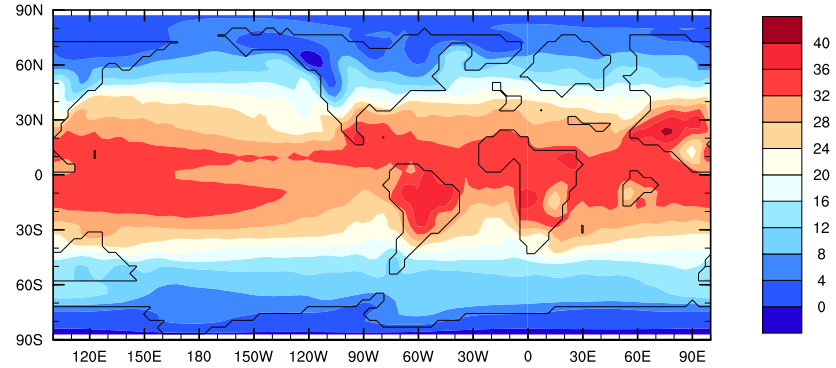

Figure 2. Forcing field: annual mean atmospheric temperature $\left(^{\circ}\right)$ at $2 \mathrm{~m}$ in height.

latitudes $\left(-1{ }^{\circ} \mathrm{C}\right.$ at $\left.90^{\circ} \mathrm{S}\right)$ are on annual average around $4{ }^{\circ} \mathrm{C}$ colder than northern high latitudes $\left(3^{\circ} \mathrm{C}\right.$ at $\left.90^{\circ} \mathrm{N}\right)$.

The prescribed wind forcing displays similar patterns as in the pre-industrial setup (not shown). However, the variability of late Paleocene winds is much stronger than the variability of the pre-industrial state. The highest variability is found in the stormtrack regions at higher latitudes, while around the Equator, winds are comparable to pre-industrial conditions. The atmospheric climate state has been evaluated in an earlier study using the same model version by Heinemann et al. (2009).

The ocean has a mean temperature of $14.7^{\circ} \mathrm{C}$ (preindustrial: $5.6^{\circ} \mathrm{C}$ ) and a global annual mean SST of $24.8^{\circ} \mathrm{C}$, which is in agreement with results of other climate models (Lunt et al., 2012). The northern high latitudes reach maximum SST of $12.8^{\circ}$ Cin Northern Hemisphere summer (JJA), but the sea surface of the central Arctic Ocean does not get warmer than $4{ }^{\circ} \mathrm{C}$. The southern high latitudes show maximum SST of $17.8^{\circ} \mathrm{C}$ in austral summer (DJF). In the presented setup, no sea ice occurs; in each hemisphere's winter, the ocean stays completely ice free. The simulated high-latitude SST are in general agreement with the reconstructions for the Southern Ocean (Thomas et al., 2002), but do not fit the extreme proxy data assumptions of Sluijs et al. (2006) for the Arctic Ocean (for further discussion, see Heinemann et al., 2009). The meridional cross sections of the Pacific and the Atlantic Ocean (Fig. 3) differ from each other in their vertical temperature profiles. While the Atlantic features homogeneous relatively warm temperatures over the largest parts of the water column, the temperature gradient in the Pacific is much more pronounced. Differences in deep sea temperatures reach up to $\sim 5^{\circ} \mathrm{C}$ between the two basins. While deep sea temperatures for the Atlantic $\left(13^{\circ} \mathrm{C}\right)$ are in line with proxies (Tripati and Elderfield, 2005), the deep Pacific $\left(8^{\circ} \mathrm{C}\right)$ seems comparatively cold.

The late Paleocene ocean in our simulations has a mean salinity of 34.31 (pre-industrial: 34.67 ) and a mean SSS of 33.77. Within the subtropics, regions of elevated SSS around 36 emerge, while higher latitudes show generally lower values (Fig. 3). The Atlantic Ocean has the highest SSS; here, the annual mean surface salinity amounts to 35.06 , 
(a)

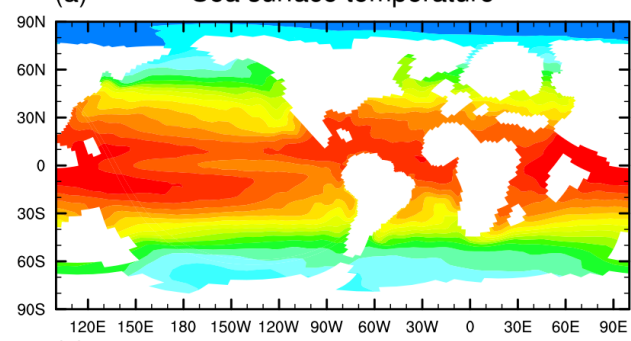

(c)

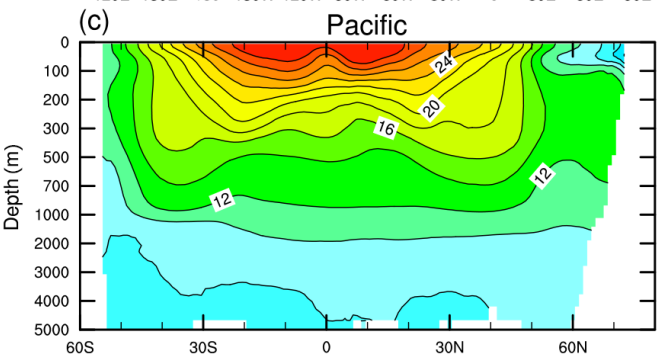

(e)

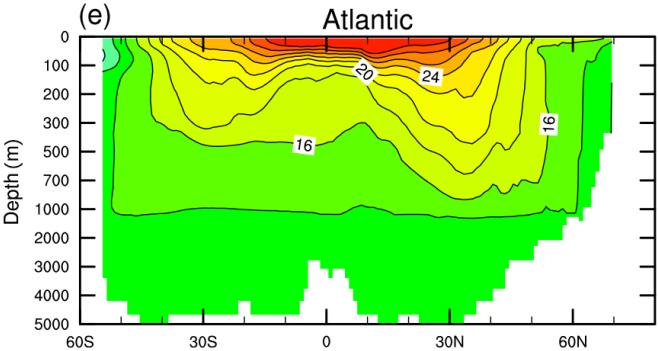

(b)
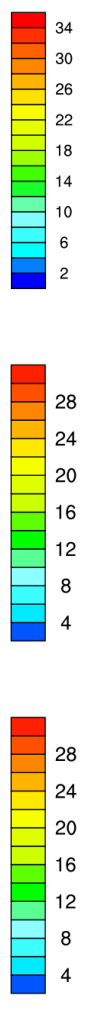

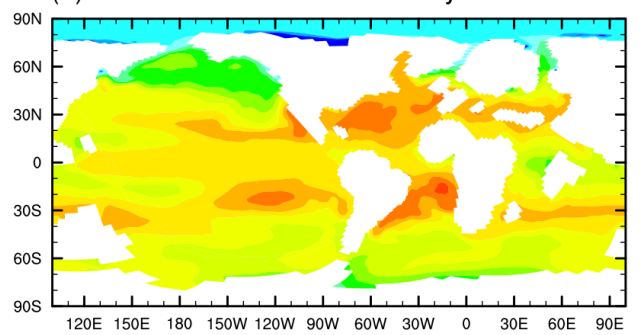

Pacific
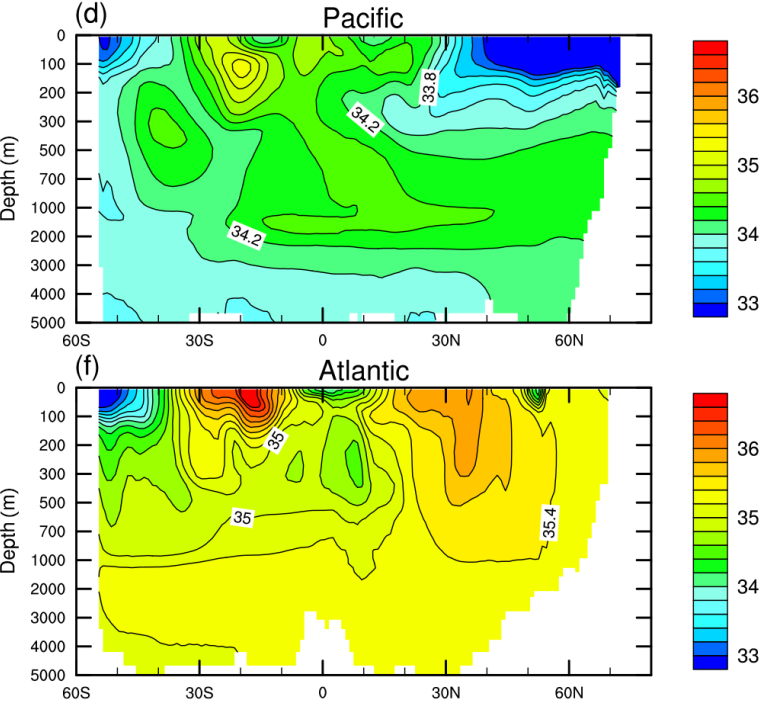

Figure 3. Sea surface temperature $\left({ }^{\circ} \mathrm{C}\right)$ (left) and salinity (right) for the surface (a, b), Pacific (c, d), and Atlantic (e, f) averaged meridional crosscut. Note the nonlinear vertical axes, used to zoom in on the upper ocean layers.

and maximum salinities of 36.9 in the North Atlantic and 37.4 in the South Atlantic are reached. The upper $1000 \mathrm{~m}$ of the basin reveal the advection of more saline waters from the Tethys around $30^{\circ} \mathrm{N}$ and less saline waters from the Southern Ocean. At depths greater than $1000 \mathrm{~m}$, the Atlantic basin salinity is characterized by homogeneous distributions, except for the small tongue of slightly less saline Antarctic bottom water (AABW) extending until $20^{\circ} \mathrm{S}$ (Fig. 3), mirroring the weak vertical mixing and hence strong stratification. The Pacific is much more heterogeneous in terms of vertical salinity distribution. In the northern Pacific, the Arctic inflow of water causes very low surface ocean salinities up to $30^{\circ} \mathrm{N}$. The Southern Hemisphere and even parts of the northern deep Pacific are dominated by less saline AABW. The inflow of Atlantic water via the Central American Seaway (strongest net inflow in the uppermost $100 \mathrm{~m}$ ) causes the highest salinities in the Pacific (Fig. 3). Here, the more saline waters descend, and are then transported northward. This gradient between the southern (low salinity) and northern (high salinity) Pacific shapes the vertical salinity profile. The Arctic Ocean's mean surface salinity amounts to 27.13 . This low salinity is interpreted as an effect of freshwater inflow due to an intensified hydrological cycle in a warmer atmosphere and as an effect of the shape of the ocean basin.
Low surface salinities and a poorly ventilated water column are also derived from proxy data (Pagani et al., 2006b; Waddell and Moore, 2008). The bathymetry prevents any deepwater exchange with the surrounding oceans, and hence contributes to a sharper stratification of the Arctic Ocean and its low-salinity cap. There is no additional amplifying mechanism for mixing of Arctic waters due to the absent sea ice formation and consequent brine production.

Salinity and temperature profiles are mainly shaped by the meridional overturning circulation (MOC) (Fig. 4). The large-scale circulation structures are generally similar to modern conditions, but the late Paleocene Atlantic is dominated by just one large-scale circulation cell in our simulation (spreading over nearly the whole basin up to a depth of $4000 \mathrm{~m}$ ), causing more homogeneous temperature and salinity distributions. The Atlantic Ocean lacks an AABW cell, while the AABW formation and spreading are much more pronounced in the Pacific. Here, formation of deepwater occurs at $70^{\circ} \mathrm{S}$. No further overturning takes place in the northern Pacific, as salinity concentrations in the surface ocean are too low, due to the Arctic Ocean water inflow. The late Paleocene climate causes the ocean to be warmer on average (compared to pre-industrial conditions), leading to increased stratification throughout the water column. The 

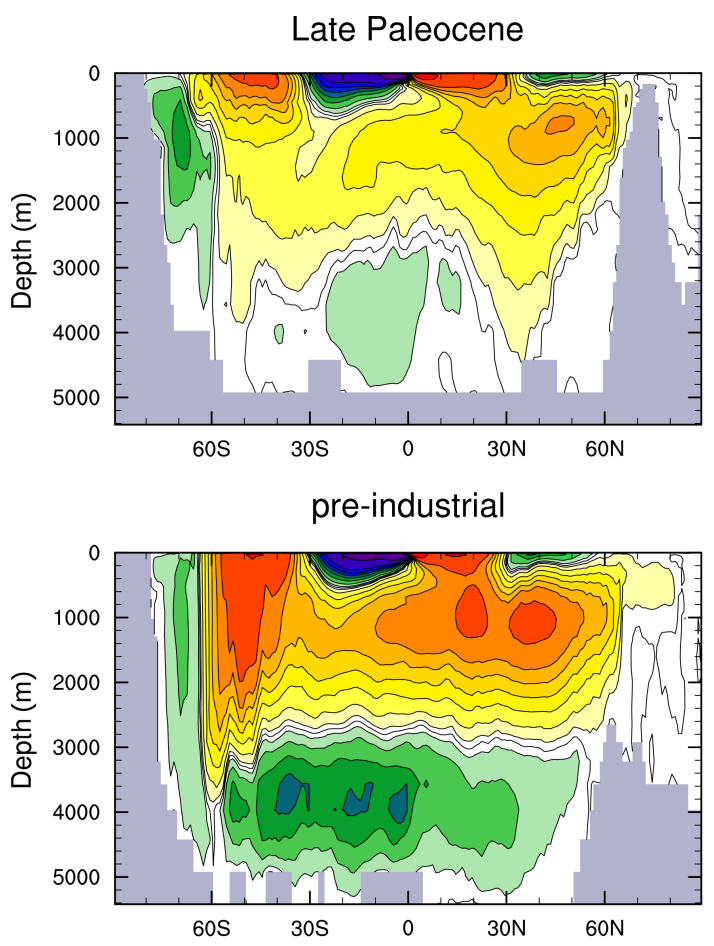

Figure 4. Globally averaged meridional overturning circulation (Sv) for the late Paleocene (top) and the pre-industrial (bottom). Positive values correspond to clockwise circulation. Pre-industrial values were calculated within CMIP5 experiments.

reduced equator-to-pole temperature gradient results in a further slowdown of the MOC. A maximum deepwater formation (for depths greater than $900 \mathrm{~m}$ ) of $\sim 15 \mathrm{~Sv}$ occurs in the Southern Ocean and the North Atlantic (Fig. 4). Southern Ocean sinking occurs in the Ross Sea, similar to other Paleocene-Eocene simulations (Sijp et al., 2014), whereas the North Atlantic deepwater source is not produced in all models.

In MPIOM, the mixed layer depth (MLD) is defined as the depth where in situ density exceeds surface water density by more than $0.125 \mathrm{~kg} \mathrm{~m}^{3}$ (sigma-t criterion). The annual global mean MLD in the late Paleocene setup levels at $52 \mathrm{~m}$ in depth. Observations suggest an annual global mean of $65 \mathrm{~m}$ for MLD in present-day oceans (de Boyer Montegut et al., 2004). Since the MLD is interpreted as an indicator of the stratification of the ocean, which apparently is stronger in a warmer climate (e.g., Wetzel et al., 2006), the reduced MLD appears to be an expected result of our model simulation. As shown in Fig. 5, the MLD has a strong seasonal signal. In boreal winter, deepwater formation takes place in the North Atlantic. In austral winter, the same deepening of MLD as an effect of convectional processes occurs in the South Pacific.
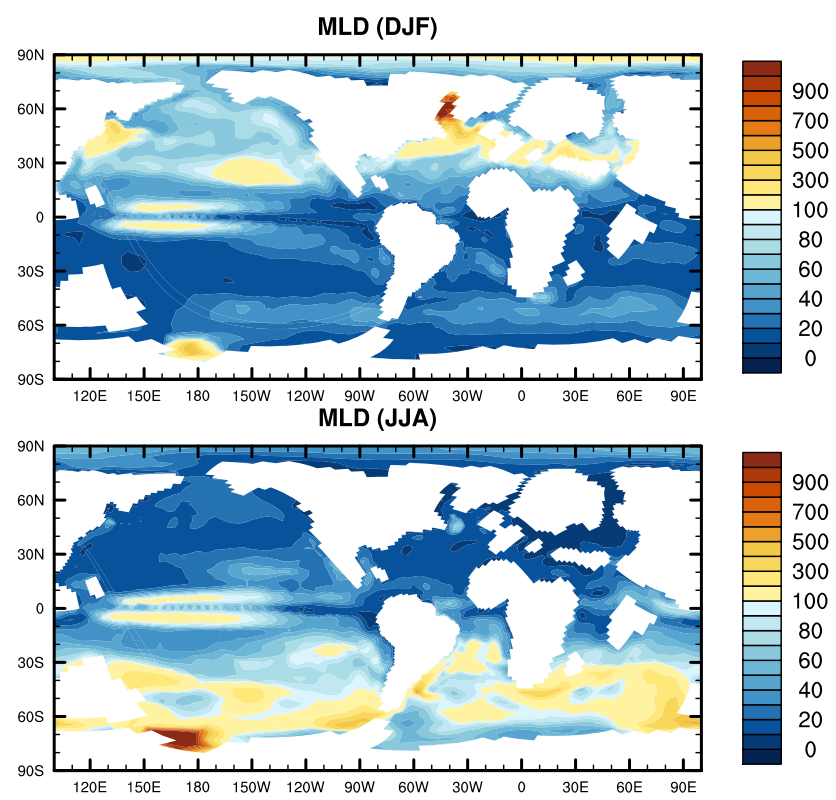

Figure 5. Mixed layer depth (m) averaged over boreal winter (DJF) and boreal summer (JJA).

\section{Late Paleocene ocean biogeochemistry}

\subsection{Air-sea exchange processes}

In this study, we aim at achieving steady-state conditions with respect to ocean biogeochemistry, in accordance with a long-term warm climate. Corresponding to the expectation of an equilibrium climate state, the annual mean $\mathrm{CO}_{2}$ flux at the atmosphere-ocean boundary is balanced around zero. The global annual mean of surface ocean $p \mathrm{CO}_{2}$ is $560 \mathrm{ppm}$ within the late Paleocene model setup. It shows highest values along the Equator and in the eastern boundary currents, along South America in the Pacific, and Africa in the Atlantic (Fig. 6), similar to the present day (Takahashi et al., 2009). While the general spatial distribution of $p \mathrm{CO}_{2}$ is mainly defined by temperature and salinity, the high $p \mathrm{CO}_{2}$ areas in the equatorial and coastal areas result from upwelling of high $p \mathrm{CO}_{2}$ and nutrient-rich waters from midocean depth.

The Atlantic Ocean is the major net emitter of $\mathrm{CO}_{2}$, with an annual outgassing of $0.41 \mathrm{GtC}$, while the Pacific Ocean balances its net fluxes around zero over the year. While high oceanic $p \mathrm{CO}_{2}$ is associated with carbon release into the atmosphere, oceanic $\mathrm{CO}_{2}$ uptake occurs in regions with low $p \mathrm{CO}_{2}$ (if $p \mathrm{CO}_{2}$ oce $<p \mathrm{CO}_{2} \mathrm{~atm}$ ). The model computes the lowest $p \mathrm{CO}_{2}$ around Antarctica, especially close to the Drake Passage, which corresponds to low salinity and TA concentrations in this area. Nevertheless, nearly the whole Southern Ocean $\left(40-80^{\circ} \mathrm{S}\right)$ is characterized by $p \mathrm{CO}_{2}$ values below the atmospheric $\mathrm{CO}_{2}$ concentration of $560 \mathrm{ppm}$. This is consistent with deepwater formation and the deep MLD 


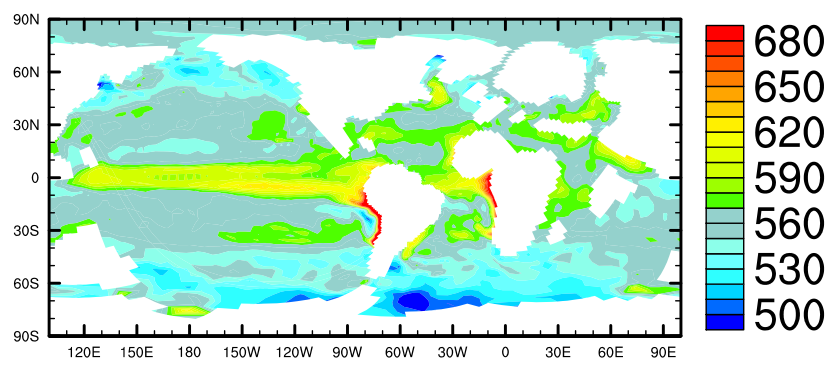

Figure 6. Annual mean surface ocean $p \mathrm{CO}_{2}(\mathrm{ppm})$.

in austral winter in the Southern Ocean. Another prominent zone of low $p \mathrm{CO}_{2}$ is located between 50 and $80^{\circ} \mathrm{N}$, with its maximum in the North Atlantic and the North Pacific. Summarized over the whole year, the Arctic Ocean acts as a $\mathrm{CO}_{2}$ sink (net uptake of $0.06 \mathrm{GtC}$ ). However, it plays a minor role in carbon uptake compared to the present day, due to the reduction in surface area of $40 \%$ and increased ocean temperature. Instead, the Indian Ocean becomes the major driver in $\mathrm{CO}_{2}$ net uptake $\left(0.31 \mathrm{GtC} \mathrm{yr}^{-1}\right)$. The southern part of the Indian Ocean is influenced by a deep mixed layer in austral winter $(>200 \mathrm{~m})$, but even parts of the northern Indian Ocean show a MLD of up to $80 \mathrm{~m}$, resulting in rather low $p \mathrm{CO}_{2}$ values in the Indian Ocean surface waters. Consistent with the solubility effect, which declines with rising temperature (Weiss, 1974), our model shows that the equatorial regions in the late Paleocene acted as a source of $\mathrm{CO}_{2}$, while the high latitudes operated as a $\mathrm{CO}_{2}$ sink. This matches the present-day simulations with HAMOCC (Ilyina et al., 2013), but during the late Paleocene, it is mainly the $\mathrm{CO}_{2}$ uptake of the Indian and Southern oceans that compensates for the $\mathrm{CO}_{2}$ outgassing in the Atlantic.

Globally, the high ocean temperatures lead to a reduced solubility of $\mathrm{CO}_{2}$ in the surface ocean, compared to preindustrial conditions. Moreover, the transfer of $\mathrm{CO}_{2}$ from the surface to intermediate and deep waters by the oceanic velocity field is reduced by the more sluggish circulation in the late Paleocene compared to the pre-industrial simulation (Fig. 4). The sluggish circulation together with the weak ocean solubility pump would act to reduce the ocean's uptake capacity of atmospheric $\mathrm{CO}_{2}$ in response to the carbon perturbation during the PETM.

\subsection{Biological production and nutrients}

Phosphate concentrations in the surface ocean show pronounced latitudinal gradients and weaker basin-to-basin differences in the late Paleocene simulation. High phosphate concentrations characterize the surface ocean at the southern high latitudes, the equatorial Pacific and the Atlantic, as well as at Northern Hemisphere mid latitudes (Fig. 7). Strong equatorial upwelling of water masses in the Atlantic and Pacific as well as moderate upwelling along the western coasts and in the Southern Ocean cause a maximum in phosphate surface concentrations in these regions. All other regions are characterized by phosphate depletion, with the Atlantic and Pacific gyres revealing the lowest phosphate concentrations in subtropical surface waters. Moreover, our simulation reveals a strong depletion in nutrients in the Arctic surface ocean, as a result of the interaction between bathymetry, stratification and freshwater input.

Generally, the phosphate and nitrogen cycles are treated similarly in the model, since they are connected via the Redfield ratio. However, bacterial processes such as nitrogen fixation and denitrification cause deviations between nitrate and phosphate distributions. In oxygen-depleted zones, denitrifying bacteria provide oxygen for remineralization, representing an additional sink for nitrate in these regions. In the late Paleocene simulation, intense oxygen minimum zones (OMZ) lead to low nitrate concentrations in the eastern boundary currents of the Atlantic and the Pacific. On a global average, the denitrification is $\sim 45 \%$ higher than in the simulation for the pre-industrial climate state (Table 1). The increased denitrification originates from the low oxygen concentrations in mid-ocean depth, which are induced by the reduced mixing of water masses during the late Paleocene. Nitrogen fixation occurs in areas where the ratio of nitrate to phosphate is lower than the (constant stoichiometric) value of $R_{\mathrm{N}: \mathrm{P}}$. This is primarily in the tropics, the North Pacific and the North Atlantic. Likewise, nitrate fixation is also higher in the late Paleocene than in the pre-industrial climate state.

The gradient in surface ocean nutrient concentrations between low and high latitudes in the Southern Hemisphere resembles the modern one, despite the homogeneous dust/iron concentration prescribed for every grid cell. This indicates that the dust climatology does not produce a strong signal at higher latitudes. Hence, in our late Paleocene setup, the iron limitation is not the major driving mechanism for preventing the surface ocean from complete consumption of nutrients, making the physical conditions at the poles accountable for it.

Surface oxygen concentration decreases from pole to Equator, confirming its strong temperature dependency (Fig. 7). Generally higher SST than under modern conditions lead to slightly lower oxygen concentrations in the surface oceans. Only in the Arctic Ocean does the low salinity counteract the temperature effect, as salinity is inversely related to oxygen solubility in seawater, according to Weiss (1970). This leads to similar oxygen concentrations/solubility like in the present-day setup.

While the physical dynamics and the export production of particulate organic carbon determine the surface concentrations of nutrients, the distribution of nutrients at depth is controlled by remineralization (Maier-Reimer, 1993). Modern nutrient and oxygen concentrations in the Pacific and Atlantic mirror the different age of the deepwater, defined by the global thermohaline circulation. In the late Paleocene simulation, the upper $1000 \mathrm{~m}$ of the water column reveal the highest phosphate concentrations in both basins, due to 
(a) Sea surface phosphate
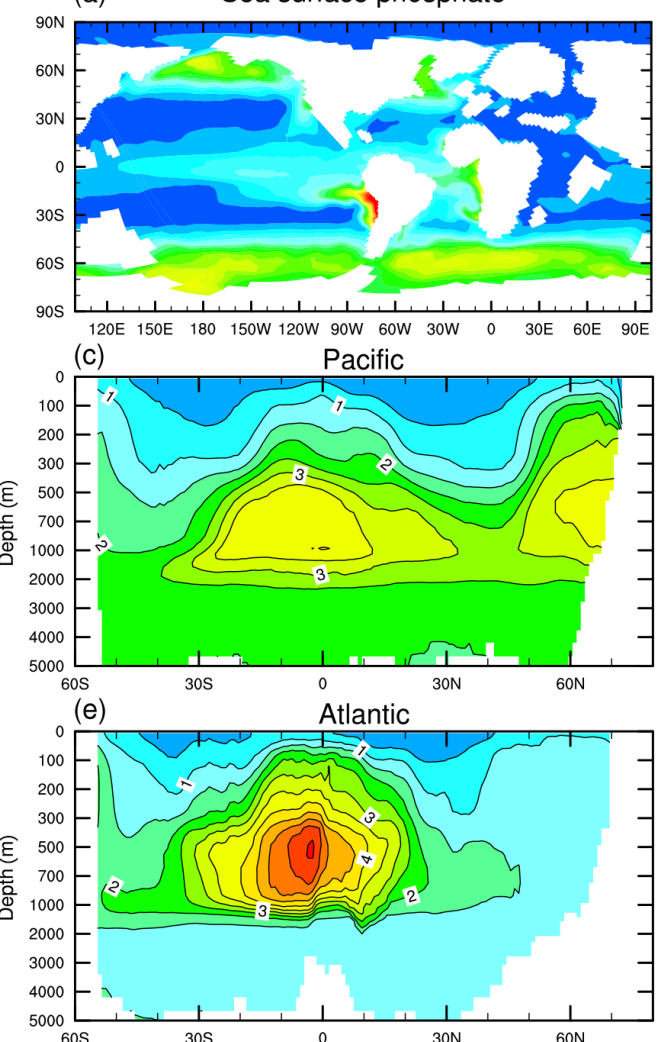

(b)
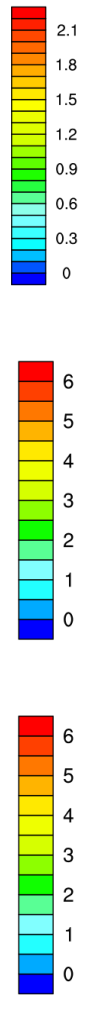
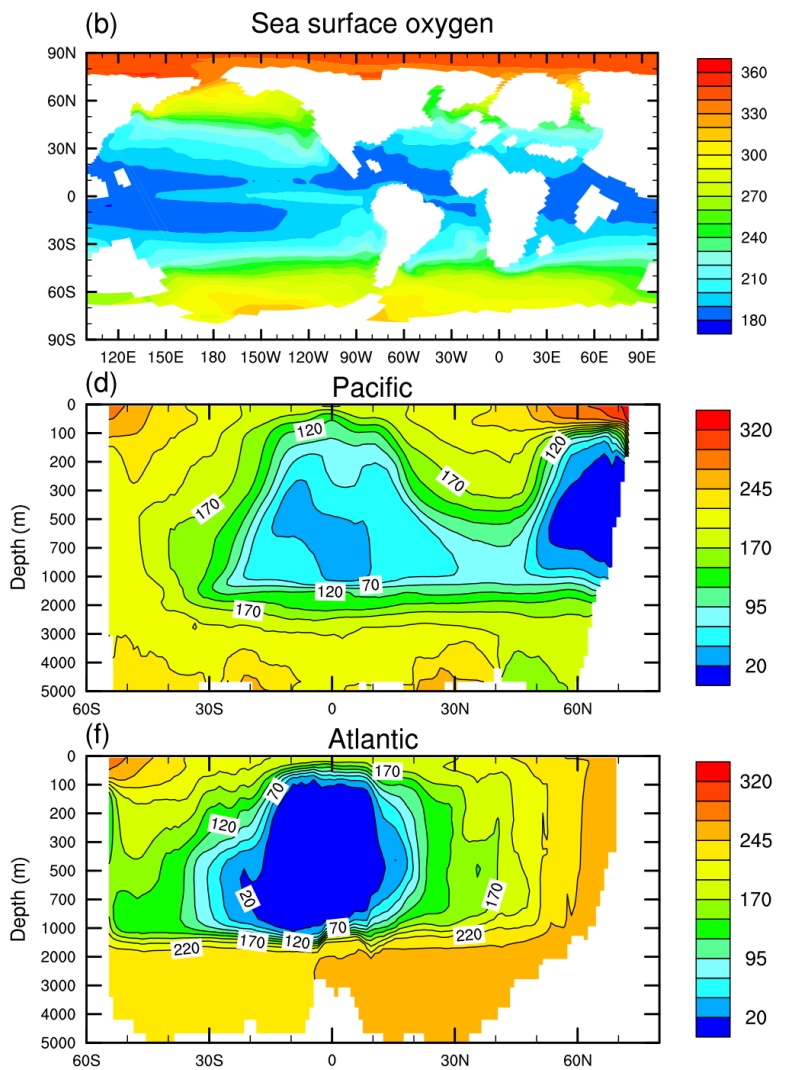

Figure 7. Phosphate (left) and oxygen (right) concentrations (both in $\mu \mathrm{mol} \mathrm{L}^{-1}$ ) for the surface (a, b), Pacific (c, d), and Atlantic (e, f) averaged meridional crosscut. Note the nonlinear vertical axes, used to zoom in on the upper ocean layers.

strong remineralization of organic matter. The phosphate concentrations at depths below $1000 \mathrm{~m}$ are rather a product of global ocean circulation, then in situ remineralization. This explains the lower phosphate concentrations in the Atlantic over the Pacific, although OM export rates (in units per area) and oxygen concentrations are higher in the Atlantic. The oxygen concentration in Pacific deepwater is highly increased (Fig. 8) compared to modern conditions, which can be attributed to Southern Ocean deepwater formation and an enhanced exchange of the Pacific and Atlantic through the Central American Seaway.

The OMZ are very pronounced within the upper $1000 \mathrm{~m}$ in both basins. Oxygen concentrations are as low as $20 \mu \mathrm{mol} \mathrm{kg}{ }^{-1}$, on meridional average, along the equatorial Atlantic and the North Pacific. The prominent OMZ are attributed to the existence of productive equatorial zones (Fig. 9) (Norris et al., 2013) and reduced mixing in a more stagnant ocean during the late Paleocene. For the Atlantic, the low oxygen concentrations along the Equator are even intensified on the meridional average, due to an additional high productivity zone along the northern continental margin of South America. In general, the Atlantic shows an increase in OM export (in units per area) of nearly $60 \%$ in comparison to the pre-industrial, although the total export increased by just
$13 \%$, due to the reduced area of the Atlantic in the late $\mathrm{Pa}$ leocene setup. However, the simulated OMZ might be somewhat overestimated, as illustrated in CMIP5 simulations. The model produces lower than observed oxygen concentrations, spreading over larger areas in the equatorial Pacific and along the western continental margin of Africa (Ilyina et al., 2013), which is typical for other global models as well (Andrews et al., 2013; Cocco et al., 2013).

The annual global primary production amounts to $\sim 59 \mathrm{GtC}$ (Table 1) in the late Paleocene simulation. The coastal upwelling regions along the western continental margins, as well as the equatorial regions of the Pacific and the Atlantic, tend to be the dominant mechanism fueling primary production (Fig. 9). Compared to modern conditions, the production along the eastern boundary currents in the Atlantic and Pacific is less pronounced. However, resulting from the open Central American Seaway, strong production arises along the northern tip of South America. The mid latitudes (nutrient-poor mid latitudinal gyres) and the Arctic Ocean exhibit sparse productivity. On the contrary, the nutrient-rich Southern Ocean is responsible for $\sim 11 \%$ of the global primary production.

The production of calcite shells follows the low silicate surface concentrations in the Atlantic, Tethys and Indian 

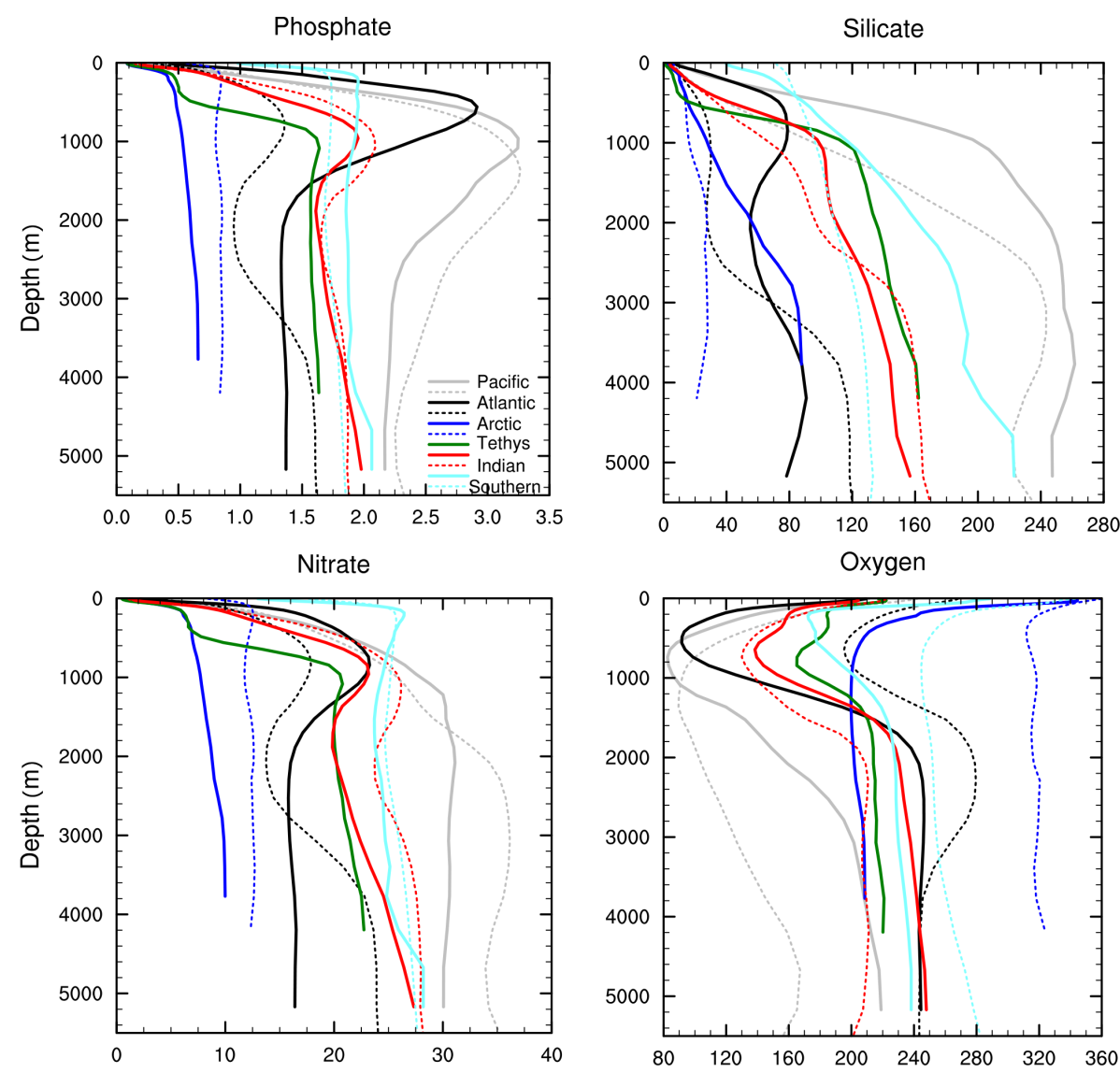

Figure 8. Globally averaged vertical profiles of phosphate, silicate, nitrate and oxygen (all in $\mu$ mol $\mathrm{L}^{-1}$ ). Solid lines show late Paleocene distributions; dotted lines show pre-industrial concentrations calculated within CMIP5 experiments.

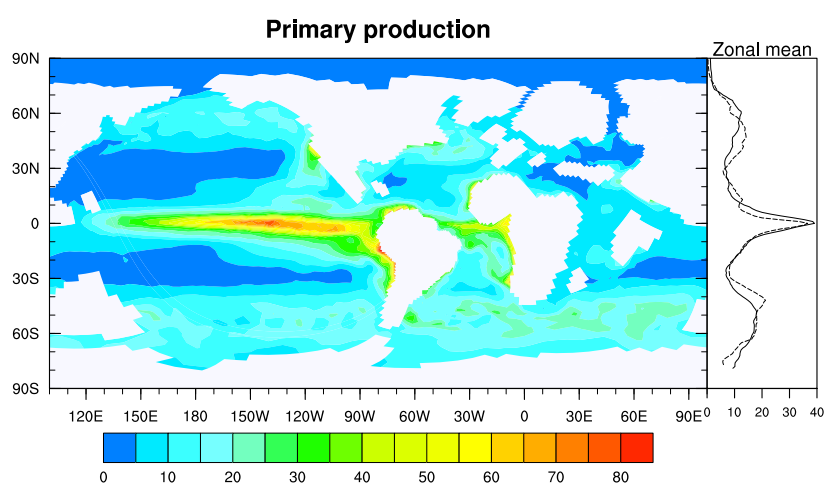

Figure 9. Annual mean primary production plotted as map and zonal average (both in mol $\mathrm{C} \mathrm{m}^{-2} \mathrm{yr}^{-1}$ ). The zonal average plot shows the primary production for the late Paleocene (solid line) and the pre-industrial (dashed line).

oceans, as well as in the western equatorial Pacific. Regions of higher silicate concentrations that correspond to upwelling locations are dominated by the production of opal shells, as implied by our modeling approach.
The export production of $\mathrm{CaCO}_{3}$ is, at $0.63 \mathrm{GtC} \mathrm{yr}^{-1}$, lower than for pre-industrial conditions (see Table 1). This leads to a $\mathrm{CaCO}_{3}: \mathrm{POC}$ export ratio of 0.07 , contrary to the PETM simulations of Panchuk et al. (2008) and Ridgwell and Schmidt (2010) suggesting a ratio of 0.2. As the $\mathrm{CaCO}_{3}$ : $\mathrm{POC}$ rain ratio is an important source of uncertainty, controlling the sedimentary $\mathrm{CaCO}_{3}$ wt $\%$ distribution, Panchuk et al. (2008) base their suggestion on an ensemble run using different export ratios. Finally, 0.2 matches best their pre-PETM CCD (3.5-4 km in depth) and $\mathrm{CaCO}_{3}$ sediment distribution. Simulations for the present-day export ratio suggest that the ratio levels more around $0.1(\sim 0.06$, Sarmiento et al. (2002); 0.1, CMIP5 runs, MPI-ESM; $<1.4$, Ridgwell and Schmidt, 2010). In our simulation, the $\mathrm{CaCO}_{3}$ : $\mathrm{POC}$ export ratio is a result of production, remineralization and sinking velocity. Because dissolution of opal is positively correlated with temperature, in a warmer ocean, more silica is available for opal production in the upper ocean (Fig. 8). This indirectly results in less $\mathrm{CaCO}_{3}$ formation in our model setup. The homogeneous dust (iron) climatology can not cause a shift from $\mathrm{CaCO}_{3}$ towards opal-producing skeletons. Thus, it can only lead to an absolute increase in the production of former iron-limiting low-productivity zones, 
(a) Sea surface alkalinity
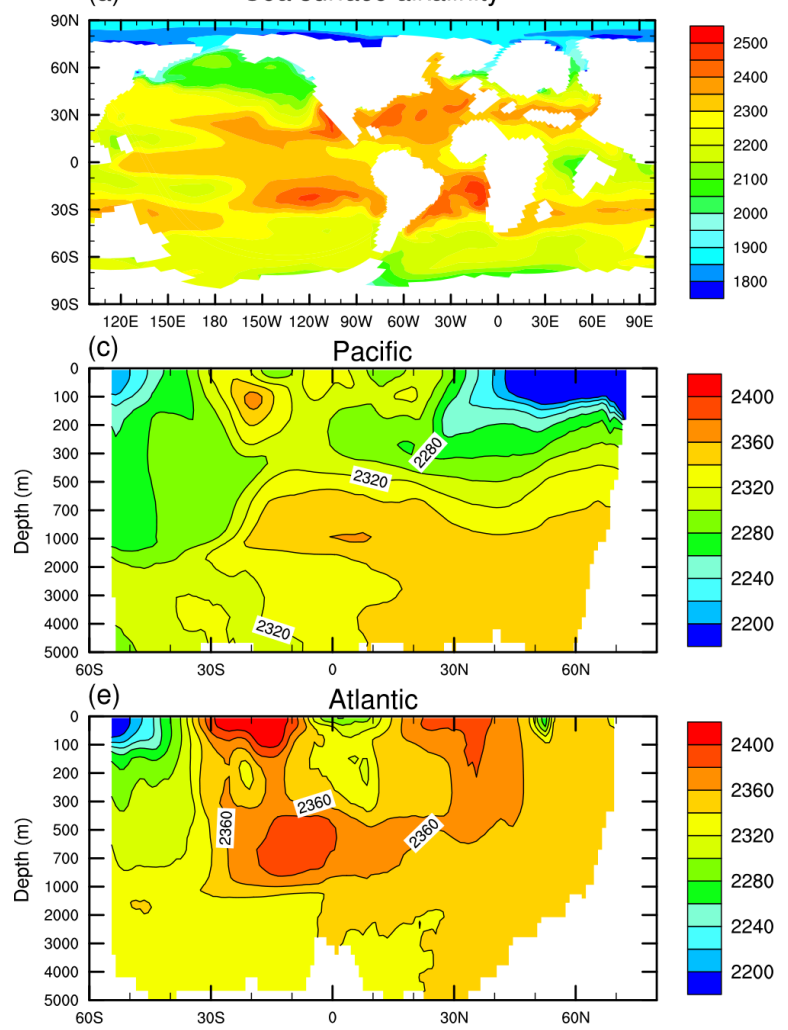

(b)
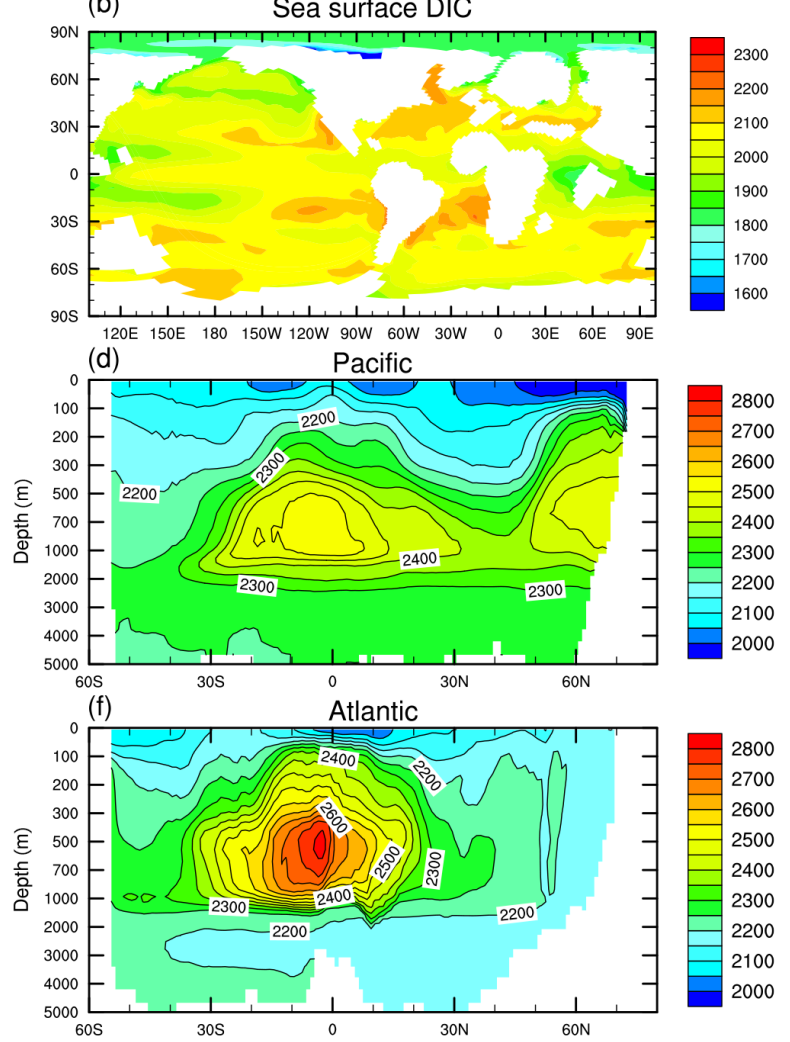

Figure 10. TA (left) and DIC (right) concentrations (both in $\mu \mathrm{mol} \mathrm{kg}{ }^{-1}$ ) for the surface (a, b), Pacific (c, d), and Atlantic (e, f) averaged meridional crosscut. Note the nonlinear vertical axes, used to zoom in on the upper ocean layers.

but can not change the proportions between the two building materials.

An interbasinal comparison reveals increased overall export fluxes in the Atlantic. Opal, $\mathrm{CaCO}_{3}$ and POC exports (in units per area) even exceed the ones in the Pacific. However, in absolute numbers, the Pacific Ocean is the main driver, covering about $50 \%$ of the global ocean surface area; it is responsible for more than $50 \%$ of POC export $\left(4.55 \mathrm{Gt} \mathrm{C} \mathrm{yr}^{-1}\right)$ globally. The strong depletion in silica in Tethys surface waters (Fig. 8) favors high $\mathrm{CaCO}_{3}$ production. As a consequence, parts of the Tethys Ocean show low surface TA. The Tethys has just a minor impact on the strength of the biolog-

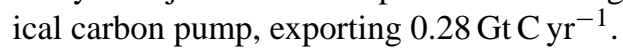

\subsection{Carbonate chemistry}

TA concentrations decrease from the Equator towards the poles, with the subtropical gyres showing both, elevated DIC and TA, compared to the surrounding surface waters (Fig. 10). The spatial patterns of surface ocean DIC and TA reproduced by the model are similar to pre-industrial conditions. The highest DIC concentrations, besides the gyres, are located in the Southern Ocean $\left(2100 \mu \mathrm{mol} \mathrm{kg}{ }^{-1}\right)$, whereas the Arctic Ocean exhibits low DIC concentrations around $1800 \mu \mathrm{mol} \mathrm{kg}^{-1}$. While the SST mainly determines the sur- face distribution of DIC, the surface TA rather reflects the structure of salinity (Maier-Reimer, 1993), which is shaped by the precipitation-evaporation gradients, leading to increased TA concentrations in the subtropics. Low salinity in the Arctic Ocean, induced by strong vertical stratification and the low exchange with the surrounding oceans (no deep-water exchange), drives the TA to very low values $\left(<1800 \mu \mathrm{mol} \mathrm{kg}^{-1}\right)$. High SST, low TA, and little $\mathrm{CO}_{2}$ uptake in the Arctic Ocean result in generally low DIC concentrations over the whole water column, reducing the Arctic Ocean's carbon storage capacity.

The surface seawater $\mathrm{CO}_{3}^{2-}$ concentration is shaped by the elevated atmospheric $\mathrm{CO}_{2}$ concentration of $560 \mathrm{ppm}$. Higher atmospheric $\mathrm{CO}_{2}$ concentrations do not have an impact on TA, but cause a shift from $\mathrm{CO}_{3}^{2-}$ to $\mathrm{HCO}_{3}^{-}$(bicarbonate). The reduced $\mathrm{CO}_{3}^{2-}$ : DIC ratio, which characterizes the prePETM carbonate chemistry, reduces the oceanic buffer capacity for atmospheric $\mathrm{CO}_{2}$ perturbations.

In the vertical profile, the maximum in DIC concentration around the Equator, spreading from 400 to $1000 \mathrm{~m}$ in depth (Fig. 10), is related to biological processes. It marks the depth at which intense dissolution and denitrification of the exported particles takes place. The aerobic remineralization of POC releases DIC and consumes oxygen, while at the 

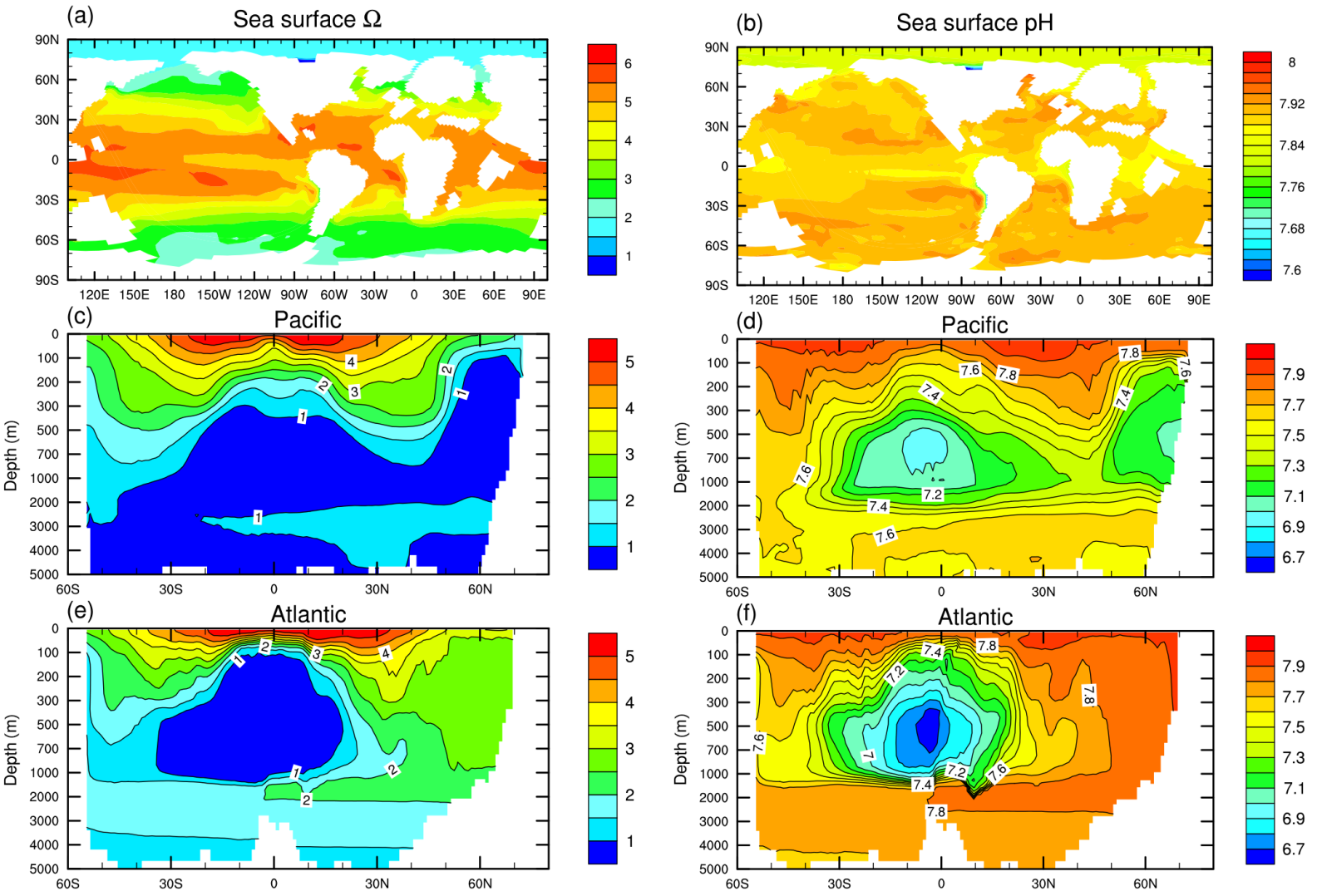

Figure 11. $\Omega$ (left) and $\mathrm{pH}$ (right) for the surface $(\mathbf{a}, \mathbf{b})$, Pacific (c, d), and Atlantic (e, f) averaged meridional crosscuts. Note the nonlinear vertical axes, used to zoom in on the upper ocean layers.

same time, the dissolution of $\mathrm{CaCO}_{3}$ and the denitrification increases the TA at $\sim 1000 \mathrm{~m}$ in depth (Fig. 10). The fact that the subsurface Atlantic (up to $1000 \mathrm{~m}$ in depth) exhibits higher TA and DIC concentrations over the Pacific can be explained by the stronger export of $\mathrm{CaCO}_{3}$ and $\mathrm{POC}$ (in units per area). In the uppermost layers of the ocean, the difference in $\mathrm{CO}_{3}^{2-}$ concentration between the Atlantic and Pacific is not evident anymore. The atmospheric $\mathrm{CO}_{2}$ concentration of $560 \mathrm{ppm}$ causes low $\mathrm{CO}_{3}^{2-}$ concentrations, reaching up to a depth of $600 \mathrm{~m}$ in both oceans. In layers beneath $2000 \mathrm{~m}$, the $\mathrm{CO}_{3}^{2-}$ concentrations within the basins show homogeneous distributions, with the Atlantic $\mathrm{CO}_{3}^{2-}$ concentrations (100$120 \mu \mathrm{mol} \mathrm{kg}{ }^{-1}$ ) being nearly twice as high as in the Pacific (60-70 $\left.\mu \mathrm{mol} \mathrm{kg}^{-1}\right)$.

The calculated global average $\mathrm{pH}$ in the surface ocean amounts to 7.9, which is in agreement with the estimate by Tyrrell and Zeebe (2004), and close to the suggestion of Ridgwell and Schmidt (2010), that late Paleocene pH surface values were $\sim 0.4$ lower than today. The surface distribution in $\mathrm{pH}$ displays a similar pattern to what we know from preindustrial $\mathrm{pH}$, albeit at lower values. Within the upwelling areas along the Equator and in front of the western continental margins, the $\mathrm{pH}$ is lower than at the mid latitudes. The
Arctic Ocean shows particularly low $\mathrm{pH}$, correlated with the very low salinities.

At depth, large parts of the Pacific are undersaturated with respect to $\mathrm{CaCO}_{3}$ (Fig. 11). However, the undersaturation is characterized by a strong gradient in the east-west direction, which is not evident in the zonally averaged $\Omega$ values (Fig. 11). The basin-wide undersaturation in the Pacific starts below a depth of $3700 \mathrm{~m}$. The horizontal gradient in $\Omega$ is even enhanced by inflow of $\mathrm{CO}_{3}^{2-}$-rich water from the Indian Ocean and undersaturated $(\Omega<1)$ near-surface waters in the eastern part of the basin. Undersaturation occurs due to biological respiration processes in intermediate waters, which correlate with very low $\mathrm{pH}$ values of up to 6.9 , computed for the uppermost $1000 \mathrm{~m}$ of the water column within the equatorial Pacific.

The elevated ocean temperatures during the late Paleocene produce a lower $\mathrm{CO}_{3}^{2-}$ saturation concentration, because the saturation concentration depends inversely on temperature. This should lead to an increased $\Omega$, in comparison to the present day, as formerly discussed in Zeebe and Zachos (2007). This effect is strong in the Atlantic, which at depth is on average around $5^{\circ} \mathrm{C}$ warmer than the Pacific in our simulation. Here, a reduced calcite saturation concentration counteracts the lower $\mathrm{CO}_{3}^{2-}$ concentrations. The undersaturation 
with respect to $\mathrm{CO}_{3}^{2-}$ in the equatorial Atlantic between 200 and $1000 \mathrm{~m}$ in depth is a result of very low $\mathrm{pH}$ in the lowlatitude subsurface ocean, caused by aerobe and anaerobe remineralization (Fig. 8). The North Atlantic and the Indian Ocean show no undersaturation with respect to $\mathrm{CaCO}_{3}^{2-}$ at all.

Our approach provides $\Omega$ distributions consistent with the three-dimensional hydrodynamical field and the biogeochemical processes as simulated for the late Paleocene ocean. We perceive a complex pattern of $\Omega$, which includes, e.g., undersaturated waters at shallower depths overlying supersaturated waters in deeper layers, as seen in the Pacific in our simulation. Local undersaturation might be of importance, since 60 to $80 \%$ of the $\mathrm{CaCO}_{3}$ export is dissolved already in the upper $1000 \mathrm{~m}$ of the water column, as shown by present-day studies (Feely et al., 2004; Ilyina and Zeebe, 2012). The assumption of a uniform basin-wide saturation horizon (depths where $\Omega=1$ ) or lysocline (depths where $\Omega=0.8$; Ridgwell and Zeebe, 2005) for the late Paleocene oceans (e.g., Panchuk et al., 2008; Zeebe et al., 2009; Cui et al., 2011), as has been made for several EMIC and box model studies, might underestimate these dissolution processes.

\subsection{Sediment composition}

The sediment compartment was initialized with $100 \%$ clay. Hence, the resulting distribution of organic matter, opal and $\mathrm{CaCO}_{3}$ in the sediment reflects water column processes. Large sedimentary opal deposits are located in the equatorial Pacific, along the eastern boundary currents and in the Southern Ocean (Fig. 12). This mirrors the nutrient-rich upwelling areas, zones where high production at the surface takes place. However, it is noticeable that the annual net sedimentation rate of opal is very small on the global scale. Since the opal remineralization rate is positively correlated with temperature, we attribute this effect to the increased deep sea temperature as compared to the pre-industrial setup of the model.

$\mathrm{CaCO}_{3}$ deposits cover wider areas, corresponding to supersaturated $(\Omega>1)$ bottom waters and $\mathrm{CaCO}_{3}$ production at the surface. The present-day apparent predominance of $\mathrm{CaCO}_{3}$ accumulation in the Atlantic and Indian oceans compared to the Pacific is also preserved in the late Paleocene simulations. A greater degree of undersaturation in the deep Pacific exists as a consequence of metabolic $\mathrm{CO}_{2}$ accumulation (Ridgwell and Zeebe, 2005). Unlike today, the Arctic and Southern oceans bear $\mathrm{CaCO}_{3}$ deposits, attributed to a regionally higher $\mathrm{CaCO}_{3}: \mathrm{POC}$ rain ratio and less corrosive bottom waters in these regions.

The upper $14 \mathrm{~cm}$ of the sediment being affected by dissolution processes contain a total $\mathrm{CaCO}_{3}$ amount of $2049 \mathrm{GtC}$. This corresponds to a global average $\mathrm{CaCO}_{3} \mathrm{wt} \%$ of 36 . The absolute amount of sedimentary $\mathrm{CaCO}_{3}$ in our simulation is slightly higher than estimates for the present day $(1610 \mathrm{Gt} C$,

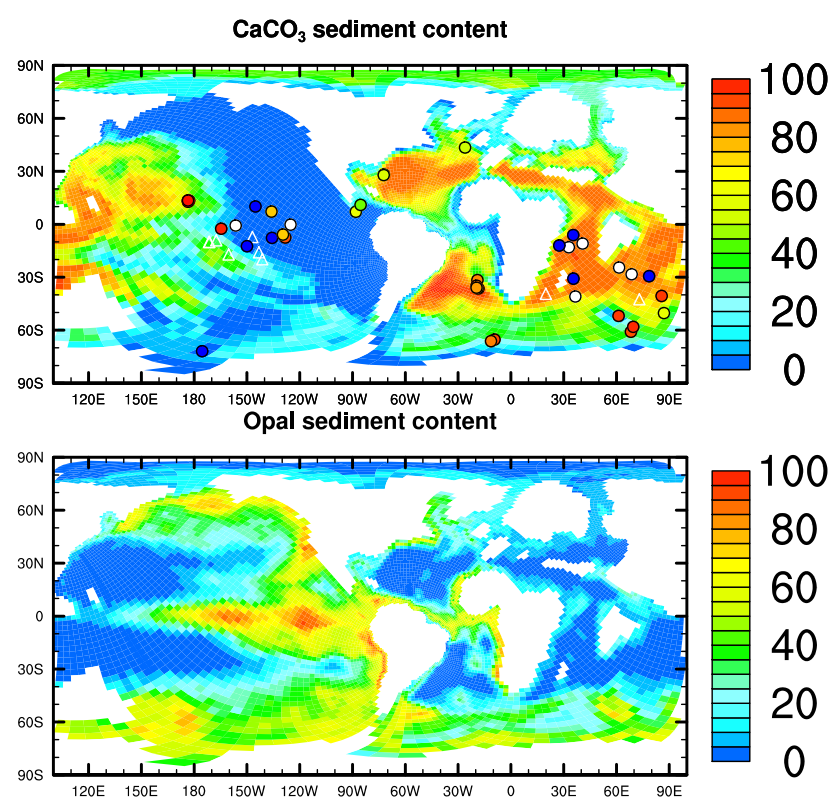

Figure 12. Sediment content of $\mathrm{CaCO}_{3}$ and opal (both in wt \%), averaged over the last 30 years of the simulation. The $\mathrm{CaCO}_{3}$ plot includes observational data points from Panchuk et al. (2008): colored dots indicate wt $\%$, white dots indicate that $\mathrm{CaCO}_{3}$ is present but wt \% is unknown, and triangles indicate a hiatus (due to nondeposition).

CMIP5 simulation with MPI-ESM; $1770 \mathrm{Gt}$ C, Archer et al., 1998). Another model study results in a lower total $\mathrm{CaCO}_{3}$ amount of $800 \mathrm{GtC}$ for the present day and a decrease to $620 \mathrm{Gt} \mathrm{C}$ for a pre-PETM setup (Zeebe, 2012).

Panchuk et al. (2008) evaluate their computed $\mathrm{CaCO}_{3}$ distribution by a compilation of late Paleocene marine sediment cores. We use the same data set to evaluate our results. Our model captures the spatial pattern and the absolute values of the compiled sediment core data relatively well (Fig. 12), yet our model calculates a much smaller $\mathrm{CaCO}_{3}$ : $\mathrm{POC}$ rain ratio. Differences between Panchuk et al. (2008) and our estimates persist in the absence of $\mathrm{CaCO}_{3}$ in the central Pacific, as well as in the abundance of $\mathrm{CaCO}_{3}$ in the North Atlantic in our results. This could be due to the different locations for Northern Hemisphere deepwater formation, which is located in the North Pacific in Panchuk et al. (2008), but in the North Atlantic in our simulation. Our model results match the South Atlantic data quite well. The same is true for western and central Pacific sediments and parts of the Indian Ocean. The mismatch in the eastern Pacific and central Indian oceans is mainly due to depth divergences between the cores and the model bathymetry. For instance, the $0 \mathrm{wt} \%$ sediment cores in the Indian Ocean display the $\mathrm{CaCO}_{3}$ content between 4000 and $4900 \mathrm{~m}$ in depth. The applied bathymetry is several $100 \mathrm{~m}$ shallower in these locations. Nevertheless, the model seems to underestimate the $\mathrm{CaCO}_{3}$ abundances in the Atlantic and Indian sectors of the Southern Ocean, while 
the Pacific sector shows, consistently with the data, very low $\mathrm{CaCO}_{3}$ wt $\%$.

\section{Summary and conclusions}

Using the biogeochemistry model HAMOCC coupled with the MPIOM ocean general circulation model, we establish a steady-state ocean biogeochemistry simulation with late $\mathrm{Pa}$ leocene boundary conditions. We present spatial and vertical tracer distributions within a warmer climate and display how the late Paleocene ocean physical state influences the biogeochemistry. We provide a general overview of major oceanic carbon cycle components in a high $\mathrm{CO}_{2}(560 \mathrm{ppm})$ world and give estimates of the PETM background climate.

The late Paleocene simulation reveals a strong stratification of water masses, which is displayed by temperature and salinity profiles, as well as the shallow MLD. These conditions are also found in other coupled atmosphere-ocean general circulation models using Eocene boundary conditions (Lunt et al., 2010). The sluggish circulation affects the atmosphere-ocean exchange fluxes of $\mathrm{CO}_{2}$ by shifting its spatial patterns; i.e., uptake in the Indian and Southern Ocean compensates for the $\mathrm{CO}_{2}$ outgassing of the Atlantic Ocean. Moreover, we infer a reduced vertical transfer of carbon from surface to intermediate and deep waters due to the more stagnant circulation in comparison to pre-industrial conditions. Nevertheless, the enhanced thermal vertical stratification is not prominent enough to prevent the supply of nutrients to surface waters and, hence, the global primary production is only slightly decreased.

The intensification of primary production along the Equator causes enhanced remineralization within the upper $1000 \mathrm{~m}$ of the Atlantic and Pacific, leading to strong OMZs. The global pattern in oxygen distribution in the intermediate and deep waters is affected by the altered continental configuration. In particular, the open Central American Seaway and deepwater formation in the South Pacific ensure the adjustment between Atlantic and Pacific oxygen concentrations.

The outcomes of the simulation show that an equilibrium $\mathrm{CO}_{2}$ exchange during the late Paleocene can be established without increased concentrations of TA, as assumed by Pearson and Palmer (2000), while the calculated surface ocean $\mathrm{pH}$ (lower than today) is in agreement with the results of Tyrrell and Zeebe (2004) and Ridgwell and Schmidt (2010). Low surface TA concentrations are positively influenced by a lower $\mathrm{CaCO}_{3}$ : opal export ratio, since less carbonate leaves the surface ocean. This effect is associated with the temperature-dependent remineralization of opal, which produces an increased silicate/opal turnover rate. The simulated export ratio lies within the range of estimates for modern conditions (Schneider et al., 2008), but falls below the estimates given by the simulations of Panchuk et al. (2008) and Ridgwell and Schmidt (2010) covering the Paleocene-
Eocene period. This difference may be a result of using quite different types of models.

While the deepwater of the Pacific is to a great extent undersaturated with respect to $\mathrm{CaCO}_{3}$, the Atlantic does not show any $\mathrm{CaCO}_{3}$ undersaturation at depths below $1000 \mathrm{~m}$. We claim that the warm temperatures in the deep Atlantic are responsible for producing an overly weak saturation gradient (by decreasing the saturation concentration) compared to other studies (e.g., Zeebe et al., 2009). The surface ocean is characterized by globally lower $\mathrm{CO}_{3}^{2-}$ concentrations than today, because of higher atmospheric $\mathrm{CO}_{2}$ concentrations.

Our results indicate that the late Paleocene climate state produced conditions in the carbonate chemistry that led to different responses of the surface and the deep ocean to a large carbon perturbation during the PETM. In the surface ocean, the lower $\mathrm{CO}_{3}^{2-}$ : DIC ratio implies a reduced carbonate buffer capacity, which would be even further reduced if the $\mathrm{CaCO}_{3}$ export from the surface would have been of the same strength as it is in the modern ocean. In the deep ocean, by contrast, elevated temperatures cause the $\mathrm{CaCO}_{3}$ saturation concentration to decrease (i.e., to increase in $\Omega$ ). Furthermore, the warm and stratified ocean reduces the transport of $\mathrm{CO}_{2}$ from the surface to greater depths. Both mechanisms lower the vulnerability of the sedimentary $\mathrm{CaCO}_{3}$ to dissolution. In summary, the upper ocean carbonate chemistry must have been more sensitive to a $\mathrm{CO}_{2}$ invasion than under modern conditions, while the deep ocean carbonate sediments were better preserved by the overlaying warm and stratified ocean water.

Acknowledgements. We thank H. Haak, who helped with the setup of the model, and M. Heinemann, who provided data for producing a late Paleocene atmospheric forcing. Moreover, we would like to thank K. Panchuk for providing the $\mathrm{CaCO}_{3}$ data set. We wish to thank K. Six for advice and helpful comments on the manuscript. The authors acknowledge the late E. Maier-Reimer for valuable insights on the model.

The service charges for this open access publication have been covered by the Max Planck Society. Finally we would like to thank the two anonymous reviewers which helped to strengthen the manuscript.

Edited by: E. Brook

\section{References}

Andrews, O. D., Bindoff, N. L., Halloran, P. R., Ilyina, T., and Le Quéré, C.: Detecting an external influence on recent changes in oceanic oxygen using an optimal fingerprinting method, Biogeosciences, 10, 1799-1813, doi:10.5194/bg-10-1799-2013, 2013.

Archer, D., Kheshgi, H., and Maier-Reimer, E.: Dynamics of fossil fuel $\mathrm{CO}_{2}$ neutralization by marine $\mathrm{CaCO}_{3}$, Global Biogeochem. Cy., 12, 259-276, doi:10.1029/98GB00744, 1998. 
Archer, D., Martin, P., Buffett, B., Brovkin, V., Rahmstorf, S., and Ganopolski, A.: The importance of ocean temperature to global biogeochemistry, Earth Planet. Sc. Lett., 222, 333-348, 2004.

Bice, K. L. and Marotzke, J.: Numerical evidence against reversed thermohaline circulation in the warm Paleocene/Eocene ocean, J. Geophys. Res., 106, 11529-11542, doi:10.1029/2000JC000561, 2001.

Bice, K. L. and Marotzke, J.: Could changing ocean circulation have destabilized methane hydrate at the Paleocene/Eocene boundary?, Paleoceanography, 17, 1018-1033, doi:10.1029/2001PA000678, 2002.

Cocco, V., Joos, F., Steinacher, M., Frölicher, T. L., Bopp, L., Dunne, J., Gehlen, M., Heinze, C., Orr, J., Oschlies, A., Schneider, B., Segschneider, J., and Tjiputra, J.: Oxygen and indicators of stress for marine life in multi-model global warming projections, Biogeosciences, 10, 1849-1868, doi:10.5194/bg-10-18492013, 2013.

Cui, Y., Kump, L. R., Ridgwell, A. J., Charles, A. J., Junium, C. K., Diefendorf, A. F., Freeman, K. H., Urban, N. M., and Harding, I. C.: Slow release of fossil carbon during the Palaeocene-Eocene Thermal Maximum, Nature Geosci, 4, 481485, doi:10.1038/ngeo1179, 2011.

de Boyer Montegut, C., Madec, G., Fischer, A. S., Lazar, A., and Iudicone, D.: Mixed layer depth over the global ocean: An examination of profile data and a profile-based climatology, J. Geophys. Res., 109, C12003, doi:10.1029/2004JC002378, 2004.

Dickens, G. R., O’Neil, J. R., Rea, D. K., and Owen, R. M.: Dissociation of oceanic methane hydrate as a cause of the carbon isotope excursion at the end of the, Paleocene Paleoceanogr., 10, 965-971, 1995.

Dunkley Jones, T., Ridgwell, A., Lunt, D. J., Maslin, M. A., Schmidt, D. N., and Valdes, P. J.: A Palaeogene perspective on climate sensitivity and methane hydrate instability, Philos. T. Roy. Soc. A: Mathematical, Physical and Engineering Sciences, 368, 2395-2415, doi:10.1098/rsta.2010.0053, 2010.

Feely, R. A., Sabine, C. L., Lee, K., Berelson, W., Kleypas, J., Fabry, V. J., and Millero, F. J.: Impact of Anthropogenic $\mathrm{CO}_{2}$ on the $\mathrm{CaCO}_{3}$ System in the Oceans, Science, 305, 362-366, 2004.

Groeger, M. and Mikolajewicz, U.: Note on the $\mathrm{CO}_{2}$ air-sea gas exchange at high temperatures, Ocean Model., 39, 284-290, 2011.

Heinemann, M., Jungclaus, J. H., and Marotzke, J.: Warm Paleocene/Eocene climate as simulated in ECHAM5/MPI-OM, Clim. Past, 5, 785-802, doi:10.5194/cp-5-785-2009, 2009.

Heinze, C. and Maier-Reimer, E.: The Hamburg Oceanic Carbon Cycle Circulation Model version "HAMOCC2s" for longtime integrations, Technical Report 20, Deutsches Klimarechenzenrum, Modellberatungsgruppe, Hamburg, 1999.

Heinze, C., Maier-Reimer, E., Winguth, A. M. E., and Archer, D.: A global oceanic sediment model for long-term climate studies, Global Biogeochem. Cy., 13, 221-250, doi:10.1029/98GB02812, 1999.

Huber, M. and Nof, D.: The ocean circulation in the southern hemisphere and its climatic impacts in the Eocene, Palaeogeogr. Palaeoclimatol. Palaeoecol., 231, 9-28, 2006.

Huber, M. and Sloan, L. C.: Heat transport, deep waters, and thermal gradients: Coupled simulation of an Eocene greenhouse climate, Geophys. Res. Lett, 28, 3481-3484, 2001.

Huber, M., Brinkhuis, H., Stickley, C. E., Döös, K., Sluijs, A., Warnaar, J., Schellenberg, S. A., and Williams, G. L.: Eocene circulation of the Southern Ocean: Was Antarctica kept warm by subtropical waters?, Paleoceanography, 19, PA4026, doi: 10.1029/2004PA001014, 2004.

Ilyina, T. and Zeebe, R. E.: Detection and projection of carbonate dissolution in the water column and deep-sea sediments due to ocean acidification, Geophys. Res. Lett., 39, L06606, doi:10.1029/2012GL051272, 2012.

Ilyina, T., Six, K. D., Segschneider, J., Maier-Reimer, E., Li, H., and Núñez-Riboni, I.: The global ocean biogeochemistry model HAMOCC: Model architecture and performance as component of the MPI-earth system model in different CMIP5 experimental realizations, J. Adv. Model. Earth Syst., 5, 287-315, doi:10.1002/jame.20017, 2013.

Jungclaus, J. H., Fischer, N., Haak, H., Lohmann, K., Marotzke, J., Matei, D., Mikolajewicz, U., Notz, D., and von Storch, J. S.: Characteristics of the ocean simulations in the Max Planck Institute Ocean Model (MPIOM) the ocean component of the MPIEarth system model, J. Adv. Model. Earth Syst., 5, 422-446, doi:10.1002/jame.20023, 2013.

Kennett, J. P. and Stott, L. D.: Abrupt deep-sea warming, palaeoceanographic changes and benthic extinctions at the end of the Palaeocene, Nature, 353, 225-229, doi:10.1038/353225a0, 1991.

Lochte, K., Ducklow, H., Fasham, M., and Stienen, C.: Plankton succession and carbon cycling at $47^{\circ} \mathrm{N} 20^{\circ} \mathrm{W}$ during the JGOFS North Atlantic Bloom Experiment, Deep Sea Res. II, 40, 91-114, 1993.

Lunt, D. J., Valdes, P. J., Jones, T. D., Ridgwell, A., Haywood, A. M., Schmidt, D. N., Marsh, R., and Maslin, M.: $\mathrm{CO}_{2}$-driven ocean circulation changes as an amplifier of Paleocene-Eocene thermal maximum hydrate destabilization, Geology, 38, 875878, 2010.

Lunt, D. J., Dunkley Jones, T., Heinemann, M., Huber, M., LeGrande, A., Winguth, A., Loptson, C., Marotzke, J., Tindall, J., Valdes, P., and Winguth, C.: A model-data comparison for a multi-model ensemble of early Eocene atmosphereocean simulations: EoMIP, Clim. Past Discuss., 8, 1229-1273, doi:10.5194/cpd-8-1229-2012, 2012.

Mahowald, N. M., Baker, A. R., Bergametti, G., Brooks, N., Duce, R. A., Jickells, T. D., Kubilay, N., Prospero, J. M., and Tegen, I.: Atmospheric global dust cycle and iron inputs to the ocean, Global Biogeochem. Cy., 19, GB4025, doi:10.1029/2004GB002402, 2005.

Maier-Reimer, E.: Geochemical cycles in an ocean general circulation model. Preindustrial tracer distributions, Global Biogeochem. Cy., 7, 645-677, doi:10.1029/93GB01355, 1993.

Maier-Reimer, E., Kriest, I., Segschneider, J., and Wetzel, P.: The HAMburg Ocean Carbon Cycle Model HAMOCC 5.1, Technical Decription Release 1.1, Tech. rep. 14, Reports on Earth System Science, Hamburg, Germany, 2005.

Marsland, S., Haak, H., Jungclaus, J., Latif, M., and Röske, F.: The Max-Planck-Institute global ocean/sea ice model with orthogonal curvilinear coordinates, Ocean Model., 5, 91-127, 2003.

Norris, R. D., Turner, S. K., Hull, P. M., and Ridgwell, A.: Marine Ecosystem Responses to Cenozoic Global Change, Science, 341, 492-498, doi:10.1126/science.1240543, 2013.

Nunes, F. and Norris, R. D.: Abrupt reversal in ocean overturning during the Palaeocene/Eocene warm period, Nature, 439, 60-63, 2006. 
Pagani, M., Caldeira, K., Archer, D., and Zachos, J. C.: An Ancient Carbon Mystery, Science, 314, 1556-1557, doi:10.1126/science.1136110, 2006a.

Pagani, M., Pedentchouk, N., Huber, M., Sluijs, A., Schouten, S., Brinkhuis, H., Sinninghe Damste, J. S., Dickens, G. R., Backman, J., Clemens, S., Cronin, T., Eynaud, F., Gattacceca, J., Jakobsson, M., Jordan, R., Kaminski, M., King, J., Koc, N., Martinez, N. C., Matthiessen, J., McInroy, D., Moore, T. C., Moran, K., O’Regan, M., Onodera, J., Palike, H., Rea, B., Rio, D., Sakamoto, T., Smith, D. C., Stein, R., St John, K. E. K., Suto, I., Suzuki, N., Takahashi, K., Watanabe, M., and Yamamoto, M.: Arctic hydrology during global warming at the Palaeocene/Eocene thermal maximum, Nature, 443, 598-598, doi:10.1038/nature05211, 2006b.

Panchuk, K., Ridgwell, A., and Kump, L.: Sedimentary response to Paleocene-Eocene Thermal Maximum carbon release: A model-data comparison, Geology, 36, 315-318, doi:10.1130/G24474A.1, 2008.

Pearson, P. N. and Palmer, M. R.: Atmospheric carbon dioxide concentrations over the past 60 million years, Nature, 406, 695-699, doi:10.1038/35021000, 2000.

Pearson, P. N., Ditchfield, P. W., Singano, J., Harcourt-Brown, K. G., Nicholas, C. J., Olsson, R. K., Shackleton, N. J., and Hall, M. A.: Warm tropical sea surface temperatures in the Late Cretaceous and Eocene epochs, Nature, 413, 481-487, doi:10.1038/35097000, 2001.

Ragueneau, O., Tréguer, P., Leynaert, A., Anderson, R. F., Brzezinski, M. A., DeMaster, D. J., Dugdale, R. C., Dymond, J., Fischer, G., François, R., Heinze, C., Maier-Reimer, E., Martin-Jézéquel, V., Nelson, D. M., and Quéguiner, B., : A review of the Si cycle in the modern ocean: recent progress and missing gaps in the application of biogenic opal as a paleoproductivity proxy, Global Planet. Change, 26, 317-365, 2000.

Ridgwell, A. and Schmidt, D.: Past constraints on the vulnerability of marine calcifiers to massive carbon dioxide release, Nature Geosci., 3, 196-200, 2010.

Ridgwell, A. and Zeebe, R.: The role of the global carbonate cycle in the regulation and evolution of the Earth system, Earth Planet. Sci. Lett., 234, 299-315, 2005.

Roberts, C. D., LeGrande, A. N., and Tripati, A. K.: Climate sensitivity to Arctic seaway restriction during the early Paleogene, Earth Planet. Sci. Lett., 286, 576-585, 2009.

Roeske, F.: A global heat and freshwater forcing dataset for ocean models, Ocean Modelling, 11, 235-297, 2006.

Sarmiento, J. L., Dunne, J., Gnanadesikan, A., Key, R. M., Matsumoto, K., and Slater, R.: A new estimate of the $\mathrm{CaCO}_{3}$ to organic carbon export ratio, Global Biogeochem. Cy., 16, 54-1-5412, doi:10.1029/2002GB001919, 2002.

Schneider, B., Bopp, L., Gehlen, M., Segschneider, J., Frölicher, T. L., Cadule, P., Friedlingstein, P., Doney, S. C., Behrenfeld, M. J., and Joos, F.: Climate-induced interannual variability of marine primary and export production in three global coupled climate carbon cycle models, Biogeosciences, 5, 597-614, doi:10.5194/bg-5-597-2008, 2008.

Sijp, W. P., von der Heydt, A. S., Dijkstra, H. A., Flögel, S., Douglas, P. M., and Bijl, P. K.: The role of ocean gateways on cooling climate on long time scales, Global Planet. Change, 119, 1-22, 2014.
Six, K. and Maier-Reimer, E.: Effects of plankton dynamics on seasonal carbon fluxes in an ocean general circulation model, Global Biogeochem. Cy., 10, 559-583, 1996.

Sluijs, A., Schouten, S., Pagani, M., Woltering, M., Brinkhuis, Henk., Damste, J. S., Dickens, G. R., Huber, M., Reichart, G.J., Stein, R., Matthiessen, J., Lourens, L. J., Pedentchouk, N., Backman, J., and Moran, K.: Subtropical Arctic Ocean temperatures during the Palaeocene/Eocene thermal maximum, Nature, 441, 610-613, 2006.

Takahashi, T., Broecker, W. S., and Langer, S.: Redfield ratio based on chemical data from isopycnal surfaces, J. Geophys. Res.Oceans, 90, 6907-6924, doi:10.1029/JC090iC04p06907, 1985.

Takahashi, T., Sutherland, S. C., Wanninkhof, R., Sweeney, C., Feely, R. A., Chipman, D. W., Hales, B., Friederich, G., Chavez, F., Watson, A., Bakker, D. C. E., Schuster, U., Metzl, N., Yoshikawa-Inoue, H., Ishii, M., Midorikawa, T., Nojiri, Y., Sabine, C., Olafsson, J., Arnarson, T. S., Tilbrook, B., Johannessen, T., Olsen, A., Bellerby, R., Körtzinger, A., Steinhoff, T., Hoppema, M., de Baar, H. J. W., Wong, C. S., Delille, B., and Bates, N. R.: Climatological mean and decadal change in surface ocean $p \mathrm{CO}_{2}$, and net sea-air $\mathrm{CO}_{2}$ flux over the global oceans, Deep Sea Res. II, 56, 554-577, 2009.

Thomas, D., Zachos, J., Bralower, T., Thomas, E., and Bohaty, S.: Warming the fuel for the fire: Evidence for the thermal dissociation of methane hydrate during the Paleocene-Eocene thermal maximum, Geology, 30, 1067-1070, 2002.

Thomas, D. J., Bralower, T. J., and Jones, C. E.: Neodymium isotopic reconstruction of late Paleocene early Eocene thermohaline circulation, Earth Planet. Sc. Lett., 209, 309-322, 2003.

Tripati, A. and Elderfield, H.: Deep-Sea Temperature and Circulation Changes at the Paleocene-Eocene Thermal Maximum, Science, 308, 1894-1898, doi:10.1126/science.1109202, 2005.

Tyrrell, T. and Zeebe, R. E.: History of carbonate ion concentration over the last 100 million years, Geochim. Cosmochim. Acta, 68, 3521-3530, doi:10.1016/j.gca.2004.02.018, 2004.

Waddell, L. M. and Moore, T. C.: Salinity of the Eocene Arctic Ocean from oxygen isotope analysis of fish bone carbonate, Paleoceanography, 23, PA1S12, doi:10.1029/2007PA001451, 2008.

Wanninkhof, R.: Relationship Between Wind Speed and Gas Exchange Over the Ocean, J. Geophys. Res., 97, 7373-7382, doi:10.1029/92JC00188, 1992.

Weiss, R.: The solubility of nitrogen, oxygen and argon in water and seawater, Deep Sea Research and Oceanographic Abstracts, 17, 721-735, 1970.

Weiss, R.: Carbon dioxide in water and seawater: the solubility of a non-ideal gas, Mar. Chem., 2, 203-215, 1974.

Wetzel, P., Maier-Reimer, E., Botzet, M., Jungclaus, J., Keenlyside, N., and Latif, M.: Effects of ocean biology on the penetrative radiation in a coupled climate model, J/ Climate, 19, 3973-3987, 2006.

Winguth, A., Shellito, C., Shields, C., and Winguth, C.: Climate Response at the Paleocene-Eocene Thermal Maximum to Greenhouse Gas Forcing - A Model Study with CCSM3, J. Climate, 23, 2562-2584, doi:10.1175/2009JCLI3113.1, 2010.

Winguth, A. M., Thomas, E., and Winguth, C.: Global decline in ocean ventilation, oxygenation, and productivity during the Paleocene-Eocene Thermal Maximum: Implications for the benthic extinction, Geology, 40, 163-266, 2012. 
Zachos, J., Pagani, M., Sloan, L., Thomas, E., and Billups, K.: Trends, rhythms, and aberrations in global climate $65 \mathrm{Ma}$ to present, Science, 292, 686-693, 2001.

Zachos, J. C., Röhl, U., Schellenberg, S. A., Sluijs, A., Hodell, D. A., Kelly, D. C., Thomas, E., Nicolo, M., Raffi, I., Lourens, L. J., McCarren, H., and Kroon, D.: Rapid Acidification of the Ocean during the Paleocene-Eocene Thermal Maximum, Science, 308, 1611-1615, 2005.

Zachos, J. C., Dickens, G. R., and Zeebe, R. E.: An early Cenozoic perspective on greenhouse warming and carbon-cycle dynamics, Nature, 451, 279-283, doi:10.1038/nature06588, 2008.

Zeebe, R. E.: LOSCAR: Long-term Ocean-atmosphere-Sediment CArbon cycle Reservoir Model v2.0.4, Geosci. Model Dev., 5, 149-166, doi:10.5194/gmd-5-149-2012, 2012.
Zeebe, R. E. and Zachos, J. C.: Reversed deep-sea carbonate ion basin gradient during Paleocene-Eocene thermal maximum, $\mathrm{Pa}-$ leoceanography, 22, PA3201, doi:10.1029/2006PA001395, 2007.

Zeebe, R. E. and Zachos, J. C.: Long-term legacy of massive carbon input to the Earth system: Anthropocene versus Eocene, Philos. T. Roy. Soc. A, 371, 20120006, doi:10.1098/rsta.2012.0006, 2013.

Zeebe, R. E., Zachos, J. C., and Dickens, G. R.: Carbon dioxide forcing alone insufficient to explain Palaeocene-Eocene Thermal Maximum warming, Nature Geosci., 2, 576-580, doi:10.1038/ngeo578, 2009. 